\title{
Inhibition of Single Routes of Intracellular Signaling is Not Sufficient to Neutralize the Biphasic Disturbance of a Retinal Endothelial Cell Barrier Induced by VEGF-A 165
}

\author{
Heidrun L. Deissler Gerhard K. Lang Gabriele E. Lang \\ Department of Ophthalmology, University of Ulm, Ulm, Germany
}

\section{Key Words}

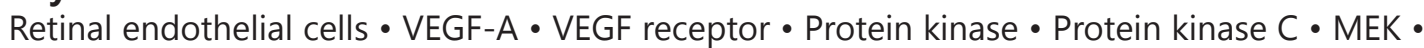
Permeability $\bullet$ Cell index measurement $\bullet$ Inhibitors $\bullet$ Tight junctions

\begin{abstract}
Background/Aims: Hallmark of diabetic macular edema is the enhanced permeability of retinal endothelial cells (REC) induced by vascular endothelial growth factor (VEGF- $\mathrm{A}_{165}$ ), which acts through activating specific receptors. To improve the predictability of inhibitors' potentials to block harmful effects of VEGF- $\mathrm{A}_{165^{\prime}}$ we investigated if its signaling pathways triggered in REC are redundant. Methods: Immortalized bovine REC monolayers were treated with inhibitors specific for various protein kinases in combination with VEGF-A ${ }_{165}$. Permeability was monitored continuously by measurements of the cell index (CI) to reveal even subtle and transient changes. Expression of tight junction (TJ) proteins was determined as additional indicator of barrier stability. Results: After a sharp but transient CI drop caused by VEGF-A ${ }_{165}$ early after its addition, further exposure resulted in a continuous CI decline over several days associated with loss of TJ protein claudin-1. Both phases were blocked by inhibition of VEGF receptor 2. Tested inhibitors of intracellular kinases had a limited or no effect, or were efficient only in certain phases of exposure to VEGF- $\mathrm{A}_{165^{\prime}}$ e.g. inhibiting protein kinase $\mathrm{C}$ only prevented the early response. High concentrations of some inhibitors even resulted in VEGFindependent barrier destabilization. Conclusions: Specific kinase inhibitors differently affect VEGF- $\mathrm{A}_{165}$-triggered processes in distinct phases of its action. VEGF- $\mathrm{A}_{165}$-initiated signaling is redundant and blocking of key proteins of single pathways is not sufficient to suppress REC barrier breakdown.

\section{Introduction}

Elevated permeability of retinal endothelial cells (REC) caused by vascular endothelial growth factor-A (VEGF-A) is a hallmark of macular edema secondary to diabetic retinopathy (DR) or retinal vein occlusion (RVO) [1, 2]. Accordingly, increased amounts of VEGF-A were 


\section{Cellular Physiology Cell Physiol Biochem 2017;42:1493-1513 \begin{tabular}{l|l|l} 
DOI: 10.1159/000479213 & (O 2017 The Author(s). Published by S. Karger AG, Basel
\end{tabular} and Biochemistry Published onlme: July 18, 2017 www.karger.com/cpb \\ Deissler et al.: Redundant VEGF-A Signaling Pathways Regulating Permeability of Retina Endothelial Cells}

observed in vitreous fluids analyzed at all stages of DR, whereas placenta growth factor (PIGF), another member of the VEGF-protein family, was found up-regulated only after transition to the proliferative form $[3,4]$. Ischemia associated with RVO leads to activation of hypoxiainducible factor 1 resulting in a stronger expression of VEGF-A and PIGF as measured in the vitreous $[2,3,5]$. Of these factors, however, only VEGF-A induced permeability of primary and immortalized REC of human or bovine origin [6-12]. Of the important splice variants, VEGF- $A_{165}$ was more effective than VEGF- $A_{121}$. Their detrimental effects were observed above a threshold concentration but were not considerably increased at higher concentrations [8, 9]. The transendothelial resistance (TER) - considered indicative of the permeability of an endothelial cell monolayer - decreased after prolonged exposure of immortalized bovine REC (iBREC) or human REC (huREC) to VEGF- $\mathrm{A}_{165}$ and this correlated with loss of plasma membrane-localized tight junction (TJ) protein claudin-1, whereas other TJ proteins (e.g. claudin-5, ZO-1) were not or only marginally affected [7-11]. In addition, cell-cell adhesive junctions formed by endothelial cells (EC) participate in the regulation of EC barrier function [13]. Internalization of the adherens junction (AJ) protein vascular endothelial cadherin (VECad) was observed early after exposure of (retinal) EC to VEGF-A, and the focal adhesion kinase (FAK) is involved in this process in human macrovascular EC of the umbilical cord (HUVEC) [14, 15].

Binding of VEGF-A ${ }_{165}$ to the VEGF receptors VEGFR1, VEGFR2 or neuropilin 1 (NRP-1), which are all expressed in REC, induces dimerization and trans-phosphorylation of these receptors followed by downstream activation of various (protein) kinases or other enzymes $[8,12,16]$. VEGF-A-induced hyperpermeability of porcine coronary venules or increase of hydraulic conductivity of mesenteric capillaries of the frog could be prevented completely by inhibition of protein kinase C (PKC), phospholipase C (PLC), or ERK1/2, also known as p42/44 MAPKs [17, 18]. Inhibition of PLC or MAPK kinase (MEK) also blocked phosphorylation of ERK1/2 in HUVEC [19]. Another VEGF-A-activated process affecting permeability of (retinal) $\mathrm{EC}$ is the generation of reactive oxygen species (ROS); the endothelial nitric oxide synthase (eNOS) seems to avert this process in primary bovine REC (BREC) [19-21]. In addition, some evidence has been published pointing to an involvement of various other protein kinases including but not limited to phosphatidylinositol-3 phosphate kinase (PI3K), Jun-N-terminal kinase (JNK) and Rho-associated coiled-coil containing protein kinase (ROCK) in the processes leading to barrier malfunction shortly after addition of VEGF-A to EC [20, 22-24]. In most of these studies, however, non-retinal EC were used, and macro- and microvascular EC behave differently. Published results on a potential involvement of PKC in VEGF-A-induced REC barrier disturbance look as if inconsistent, but contrasting outcomes may simply be due to the different timespans investigated: Inhibition of PKC prevented TER reduction early after exposure to VEGF-A, whereas PKC blockage was not sufficient to suppress VEGF-Ainduced TER reduction when iBREC were exposed for several days [7, 25]. Considering the sustained over-expression of VEGF-A in the retina of DR and RVO patients, it seems to be a plausible assumption that studying its long-term effects on REC is more relevant.

These observations invited the hypothesis that VEGF- $\mathrm{A}_{165}$-triggered signaling leading to barrier dysfunction of REC layers is most likely not restricted to one intracellular pathway and that the signaling requirements for short-term and long-term effects may differ. To investigate the pathways involved, we used specific small inhibitors of (protein) kinases described as direct targets of VEGFR1/2 or suggested to play a role in the regulation of EC permeability. Complete prevention of VEGF-A-induced iBREC barrier dysfunction indicated inhibition of important (protein) kinases or other enzymes, which might be examined further as potential therapeutic targets. By performing these experiments with specific inhibitors, we were particularly interested in the differences between short-term $(<1 \mathrm{~h})$ and long-term (up to $3 \mathrm{~d}$ ) exposure of the cells to VEGF- $\mathrm{A}_{165}$. Electric cell-substrate impedance measurements with a microelectronic biosensor system for cell-based assays allowed continuous and noninvasive measurements of VEGF effects on an iBREC monolayer during prolonged cultivation over several days $[26,27]$. In addition, we monitored the TJ protein claudin- 1 as a reliable indicator of a functional iBREC barrier. 


\section{Cellular Physiology Cell Physiol Biochem 2017;42:1493-1513

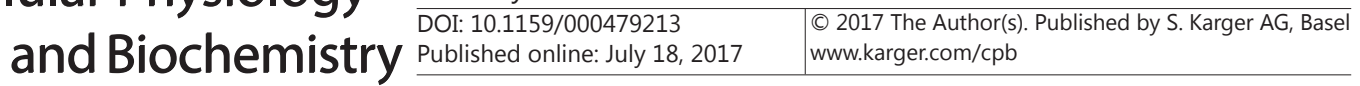 \\ Deissler et al.: Redundant VEGF-A Signaling Pathways Regulating Permeability of Retinal Endothelial Cells}

\section{Materials and Methods}

Reagents and antibodies

Characteristics of commercially available inhibitors used in this study and their providers are listed in Table 1. Recombinant human Sf21-expressed VEGF-A ${ }_{165}$ (293VE) and VEGF-A ${ }_{165 \mathrm{~b}}$ (3045-VE) were purchased from Bio-Techne (Wiesbaden, Germany). The VEGF-A-binding Fab fragment ranibizumab $(10 \mathrm{mg} / \mathrm{ml}$; Lucentis) was obtained from Novartis Pharma GmbH (Nuremberg, Germany) [44]. Epitope-specific affinitypurified rabbit polyclonal antibodies JAY.8 binding to claudin-1 and those binding to claudin-5 (Z23.JM) were bought from Thermo Fisher Scientific (Schwerte, Germany). JAY.8 detects a single band around 25 $\mathrm{kDa}$ in Western blot analyses of iBREC proteins, which was weak or absent when the cells had been treated with VEGF- $A_{165}$, and cross-reactivity of JAY.8 with claudin-3 could also be ruled out $[8,9]$. IgGs (SP1355A) purified from rabbit antiserum against VECad (CD144) were purchased from Origene Europe (Herford, Germany), mouse monoclonal antibody AC-40 from Abcam (Cambridge, UK), and horseradish peroxidaseconjugated detection antibodies binding to rabbit or mouse IgG from BioRad (Munich, Germany).

Treatment of iBREC with inhibitors and/or VEGF-A165

Telomerase-immortalized microvascular endothelial cells from bovine retina (iBREC) established in our laboratory have been characterized comprehensively elsewhere [45]. Immortalizing primary cells by ectopic expression of human telomerase reverse transcriptase is usually not associated with significant changes in important cellular processes, and the amount of human telomerase measured in iBREC is similar to that of the bovine homologue expressed early after preparation. Expression of marker proteins typical for iBREC, e.g. von Willebrand factor, VECad, claudin-1, claudin-5 was confirmed every few weeks during cultivation of the cells [8-10, 45]. Although of bovine origin, iBREC can be stimulated with human recombinant growth factors, and reproducible responses to these factors were considered indicative of a stable and authentic cell system $[8-10,45,46]$. The characteristic proliferation profile of iBREC was recorded routinely by electric cell-substrate impedance measurements (see below) as additional quality control [47]. Cells were used between passages 25 and 45 counting from the stage of primary culture, for which we had confirmed stable expression of investigated proteins.
Table 1. Characteristics of inhibitors used. a) Merck: Merck Millipore, Darmstadt, Germany; Selleckchem: Selleckchem via Absource GmbH, Munich, Germany; Sigma: Sigma Aldrich, Munich, Germany, b) L-NAME: L- $\mathrm{N}^{\mathrm{G}}$-nitroarginine methyl ester, ${ }^{\mathrm{c}}$ PDGFR: platelet derived growth factor receptor

\begin{tabular}{|c|c|c|c|c|}
\hline Inhibitor & Targeted protein & $\mathrm{IC}_{50}$ & References & Providera) \\
\hline \multirow[t]{3}{*}{ Akti-1/2 } & Akt1 & $58 \mathrm{nM}$ & \multirow[t]{3}{*}{ [28] } & \multirow[t]{3}{*}{ Merck } \\
\hline & Akt2 & $210 \mathrm{nM}$ & & \\
\hline & Akt3 & $2.12 \mu \mathrm{M}$ & & \\
\hline \multirow{4}{*}{$\begin{array}{l}\text { GF 109203X } \\
\text { (BIM I, Bis I or } \\
\text { Gö6850) }\end{array}$} & $\mathrm{PKC} \alpha$ & $20 \mathrm{nM}$ & \multirow[t]{4}{*}{ [29] } & \multirow[t]{4}{*}{ Merck } \\
\hline & PKC $\beta I$ & $17 \mathrm{nM}$ & & \\
\hline & PKC $\beta I I$ & $16 \mathrm{nM}$ & & \\
\hline & $\mathrm{PKC}_{\gamma}$ & $20 \mathrm{nM}$ & & \\
\hline KT5720 & PKA & $56 \mathrm{nM}$ & {$[30]$} & Merck \\
\hline \multirow[t]{3}{*}{ L-NAMEb) } & nNOS & $15 \mathrm{nM}$ & \multirow[t]{3}{*}{ [31] } & \multirow[t]{3}{*}{ Selleckchem } \\
\hline & eNOS & $39 \mathrm{nM}$ & & \\
\hline & iNOS & $4.4 \mu \mathrm{M}$ & & \\
\hline \multirow[t]{3}{*}{ LY294002 } & PI3K $\alpha$ & $500 \mathrm{nM}$ & \multirow[t]{3}{*}[32]{} & \multirow{3}{*}{$\begin{array}{l}\text { Selleckchem, } \\
\text { Sigma }\end{array}$} \\
\hline & PI3K $\beta$ & $970 \mathrm{nM}$ & & \\
\hline & PI3K $\delta$ & $570 \mathrm{nM}$ & & \\
\hline \multirow[t]{2}{*}{ PF-562271 } & FAK & $1.5 \mathrm{nM}$ & \multirow[t]{2}{*}[33]{} & \multirow[t]{2}{*}{ Selleckchem } \\
\hline & Pyc2 & $14 \mathrm{nM}$ & & \\
\hline \multirow{2}{*}{\multicolumn{2}{|c|}{$\begin{array}{l}\text { PD98059 MEK1 } \\
\text { (does not inhibit ERK, p38MAPK, JNK) }\end{array}$}} & $2 \mu \mathrm{M}$ & [34] & Selleckchem \\
\hline & & & & \\
\hline \multirow[t]{2}{*}{ PP2 } & Lck & $4 \mathrm{nM}$ & \multirow[t]{2}{*}[35]{} & Merck, \\
\hline & Fyn & $5 \mathrm{nM}$ & & Selleckchem \\
\hline \multirow[t]{6}{*}{ PI-103 } & PI3K $\alpha$ & $2 \mathrm{nM}$ & \multirow[t]{6}{*}[36]{} & \multirow[t]{6}{*}{ Selleckchem } \\
\hline & $\mathrm{PI} 3 \mathrm{~K} \beta$ & $3 \mathrm{nM}$ & & \\
\hline & PI3K $\delta$ & $3 \mathrm{nM}$ & & \\
\hline & $\mathrm{PI} 3 \mathrm{~K} \gamma$ & $15 \mathrm{nM}$ & & \\
\hline & mTOR & $30 \mathrm{nM}$ & & \\
\hline & DNA-PK & $23 \mathrm{nM}$ & & \\
\hline Saracatinib & c-Src & $2.7 \mathrm{nM}$ & [37] & Selleckchem \\
\hline (AZD0530) & $\mathrm{v}-\mathrm{Abl}$ & $30 \mathrm{nM}$ & & \\
\hline \multirow[t]{2}{*}{ SB202190 (FHPI) } & p38 & $50 \mathrm{nM}$ & \multirow[t]{2}{*}[22]{} & \multirow[t]{2}{*}{ Selleckchem } \\
\hline & p38 $\beta$ & $100 \mathrm{nM}$ & & \\
\hline SP600125 & JNK1 & $40 \mathrm{nM}$ & [38] & Selleckchem \\
\hline & JNK2 & $40 \mathrm{nM}$ & & \\
\hline & JNK3 & $100 \mathrm{nM}$ & & \\
\hline Tivozanib & VEGFR1 & $30 \mathrm{nM}$ & [39] & Merck, \\
\hline (KRN951, AV-951) & VEGFR2 & $6.5 \mathrm{nM}$ & & Selleckchem \\
\hline & VEGFR3 & $15 \mathrm{nM}$ & & \\
\hline & PDGFR $\alpha c)$ & $40 \mathrm{nM}$ & & \\
\hline & PDGFR $\beta$ & $49 \mathrm{nM}$ & & \\
\hline U73122 & PLC & $1 \mu \mathrm{M}$ & {$[40]$} & Selleckchem \\
\hline Wortmannin & PI3K & $5 \mathrm{nM}$ & [41] & Merck \\
\hline Y27632 & ROCK1 & $140 \mathrm{nM}$ & [42] & Selleckchem \\
\hline & ROCK2 & $300 \mathrm{nM}$ & & \\
\hline ZM323881 & VEGFR2 & $<2 \mathrm{nM}$ & [43] & Selleckchem \\
\hline & VEGFR1 & $>50 \mu \mathrm{M}$ & & \\
\hline
\end{tabular}




\section{Cellular Physiology Cell Physiol Biochem 2017;42:1493-1513 \\ \begin{tabular}{ll|l} 
and Biochemistry & $\begin{array}{l}\text { DOI: 10.1159/000479213 } \\
\text { Published online: July 18, } 2017\end{array}$ & $\begin{array}{l}\text { ( ) 2017 The Author(s). Published by S. Karger AG, Basel } \\
\text { www.karger.com/cpb }\end{array}$ \\
\hline
\end{tabular} \\ Deissler et al.: Redundant VEGF-A Signaling Pathways Regulating Permeability of Retinal Endothelial Cells}

iBREC were cultivated in Endothelial Cell Growth Medium MV (ECGM; Promocell, Heidelberg, Germany) containing $1 \mathrm{~g} / \mathrm{l}$ glucose, $0.4 \%$ Endothelial Cell Growth Supplement/H (ECGS/H),


$5 \%$ fetal bovine serum (FBS) on fibronectin-coated (50 $\mu \mathrm{g} / \mathrm{ml}$; BD Biosciences, Corning, Amsterdam, The Netherlands) surfaces as previously described $[7-10,45]$. All experiments were performed and repeated at least twice with confluent iBREC monolayers formed after cultivation for three days. Control cells were identically processed in medium only lacking the effector(s) under investigation. To avoid cells' responses to $\mathrm{pH}$ or temperature fluctuations, fresh culture medium was always sufficiently pre-equilibrated. Inhibitors were dissolved in dimethyl sulfoxide (DMSO; Sigma-Aldrich, Munich) or N,N-dimethyl formamide (DMF; Sigma-Aldrich) to result in final solvent concentrations below $0.05 \%$ in the culture medium which did not affect cell morphology or behavior.

Prior to experiments with confluent iBREC, ECGM was replaced with serum-reduced medium (SRM; same as ECGM but without hEGF and containing $0.25 \%$ FBS and $1 \mu \mathrm{g} / \mathrm{ml}$ fibronectin) for $24 \mathrm{~h}$ before VEGF-A $_{165}(50 \mathrm{ng} / \mathrm{ml}$ final concentration) was added. Cells were harvested at different time points covering the monitored intervals indicated in the Results section for preparation and analyses of subcellular fractions. To evaluate the effects of various protein kinase inhibitors, iBREC pre-cultivated in SRM for $24 \mathrm{~h}$ were exposed to these substances for $2 \mathrm{~h}$ before VEGF- $\mathrm{A}_{165}(50 \mathrm{ng} / \mathrm{ml}$ final concentration) was added. Extracts or fractions thereof were prepared from the cells $24 \mathrm{~h}$ later. Final concentrations of the inhibitors used are provided in Tables 2 and 3.

\section{Preparation of protein extracts}

Fresh or frozen cell pellets were subjected to subsequently carried out extraction steps with different buffers (ProteoExtract Subcellular Proteome Extraction Kit, Merck Millipore, Darmstadt, Germany) resulting in subcellular fractions containing proteins localized in the cytoplasm, in membranes/organelles, or components of the cytoskeleton according to the manufacturer's instruction; whole cell extracts were prepared as previously described $[8,9,46,47]$.

\section{Western blot analyses and ELISA}

For Western blot analyses, proteins in whole cell lysates from $\sim 6 \times 10^{5}$ cells or subcellular fractions from $\sim 1.5 \times 10^{5}$ cells were separated by SDS-polyacrylamide electrophoresis under reducing conditions in precast 4-20\% gradient gels (Mini-PROTEAN TGX gel, BioRad) followed by electroblotting in transfer buffer (25 mM Tris, 192 mM glycine, 20\% methanol, pH 8.4) onto a polyvinylidene difluoride membrane (BioRad) [46]. Antigen-bound primary antibodies were detected with appropriate IgG-horseradish peroxidase conjugates (1:7500 in $\mathrm{Ca}^{2+} / \mathrm{Mg}^{2+}$-free phosphate buffered saline (PBSd), 0.1\% Tween-20; BioRad) and the ECL chemiluminescence kit (Pierce ECL Plus Western Blotting Substrate, Thermo Fisher Scientific) according to the supplier's protocol. Chemiluminescence signals were visualized by exposing X-ray films (Hyperfilm ECL, GE Healthcare, VWR, Darmstadt, Germany) or by direct scanning with the imaging system Fusion Pulse TS (Vilbert Lourmat, VWR). For signal quantification, peak volumes of the corresponding bands (e.g. specific for claudin-1, claudin-5, or VECad) were determined with Evolution Capt software (Vilbert Lourmat) and standardized in relation to those of actin. To compare independent experiments, values were normalized in relation to those obtained from similar processing of control cells.

VEGF-A was measured with the Quantikine ELISA Canine VEGF-A Immunoassay Kit (CAVE00, BioTechne), which can be used to determine human, canine and bovine VEGF-A in cell culture supernatants and protein extracts (personal communication). The recovery rate of human VEGF-A $\mathrm{A}_{165}$ was similar to that of canine VEGF- $A_{165}$ described in the product information. Subcellular fractions $\left(100 \mu \mathrm{l} ; \sim 7.5 \times 10^{5}\right.$ cells $)$ or whole cell extracts ( $10 \mu \mathrm{l} ; \sim 3 \times 10^{6}$ cells) were diluted with $900 \mu \mathrm{l}$ or $990 \mu \mathrm{l}$ PBSd, respectively, and four aliquots of $200 \mu \mathrm{l}$ were used according to the manufacturer's instructions. Analyte-dependent absorbance was measured at $450 \mathrm{~nm}$ (reference wavelength: $570 \mathrm{~nm}$ ) with an Infinite 200Pro spectrophotometer controlled by Tecan i software (Tecan, Crailsheim, Germany). In parallel, a standard curve in the range 0 to $1250 \mathrm{pg} / \mathrm{ml}$ was generated with recombinant Sf21-expressed VEGF-A included in the kit, allowing quantification of VEGF-A in samples containing more than $20 \mathrm{pg} / \mathrm{ml}$.

Immunofluorescence staining

Confluent iBREC cultivated on fibronectin-coated two-chamber slides ( $\mathrm{x}$-well PCA Tissue Culture Chambers; Sarstedt, Nuembrecht, Germany) or on polyethylene terephthalate membrane inserts pre-coated 


\section{Cellular Physiology Cell Physiol Biochem 2017;42:1493-1513 \\ \begin{tabular}{ll|l} 
and Biochemistry & $\begin{array}{l}\text { DOI: 10.1159/000479213 } \\
\text { Publisned online: July 18, } 2017\end{array}$ & $\begin{array}{l}\text { ( ) } 2017 \text { The Author(s). Published by S. Karger AG, Basel } \\
\text { www.karger.com/cpb }\end{array}$ \\
\hline
\end{tabular} \\ Deissler et al.: Redundant VEGF-A Signaling Pathways Regulating Permeability of Retinal Endothelial Cells}

with fibronectin $\left(0.3 \mathrm{~cm}^{2}\right.$, pore size $0.4 \mu \mathrm{m}$; BioCoat, Corning) were treated with effectors as described above. After removal of the chamber, slides or membrane inserts were thoroughly washed in PBSd. Subsequently fixed $\left(10 \mathrm{~min}\right.$ in methanol at $\left.-20^{\circ} \mathrm{C}\right)$ cells were treated with blocking solution $(10 \% \mathrm{FBS} / \mathrm{PBSd}$ or $10 \%$ ImmunoBlock/PBSd; Roth, Karlsruhe, Germany) for $60 \mathrm{~min}$. For the detection of specific antigens, slides/ membrane inserts were exposed for $1 \mathrm{~h}$ to antibodies (diluted in 1\% FBS/PBSd or 1\% ImmunoBlock/PBSd) raised against the $C$-terminal region of human claudin-1 (1:250, ARP33623, Aviva, Biozol, Eching, Germany), binding to claudin-5 (Z23.JM; 1:250), or recognizing VECad (SP1355A; $6 \mu \mathrm{g} / \mathrm{ml}$ ). After washing in PBSd, slides/membrane inserts were then incubated for $30 \mathrm{~min}$ with Alexa Fluor 594-conjugated goat F(ab') fragments (1:500) binding to rabbit IgG (Thermo Fisher Scientific) and washed. Eventually the cells were embedded in ProLong Gold Antifade Mountant with DAPI (Thermo Fisher Scientific) for examination by fluorescence microscopy (Leica DM4000B, Wetzlar, Germany) [46, 47].

\section{Cell index measurement}

iBREC barrier stability was monitored by performing continuous electric cell-substrate impedance measurements using the microelectronic biosensor system for cell-based assays xCELLigence RTCA DP (Acea, OLS, Bremen, Germany) [26, 27]. For each condition tested, at least four replicates were analyzed essentially as previously described [47]. Impedance was measured between electrodes in an individual well of an E-Plate VIEW 16 PET (Acea) and calculated as the unit-free parameter cell index CI= $\left(\mathrm{Z}_{\mathrm{i}}-\mathrm{Z}_{0}\right) / 15 \Omega$ (RTCA Software 2.0, Acea). In this formula $\mathrm{Z}_{\mathrm{i}}$ is the impedance measured at an individual time point and $\mathrm{Z}_{0}$ the impedance read at start of the experiment. E-Plates were coated with $50 \mu \mathrm{g} / \mathrm{ml}$ fibronectin (overnight at $4^{\circ} \mathrm{C}$ or $1 \mathrm{~h}$ at $37^{\circ} \mathrm{C}$ ) and equilibrated with $150 \mu \mathrm{ECGM}$ in each of the wells at $37^{\circ} \mathrm{C}$ in the incubator for at least $1 \mathrm{~h}$ before background measurements were performed. Afterwards, $1.2 \times 10^{4}$ iBREC in $50 \mu \mathrm{l}$ ECGM were seeded per well and CI was recorded every 15 min within the first $24 \mathrm{~h}$ and then every hour until a stable value of $\mathrm{CI} \approx 20$ was reached $3 \mathrm{~d}$ after seeding, indicative of a tight confluent monolayer. Culture medium was replaced by $200 \mu \mathrm{l}$ SRM and after incubation for $24 \mathrm{~h}$ (CI measurement every $15 \mathrm{~min}$ ), $100 \mu \mathrm{l}$ of the medium was exchanged for $80 \mu \mathrm{l}$ SRM containing (protein) kinase inhibitors of which final concentrations are listed in Tables 2 and 3. CI was determined every $5 \mathrm{~min}$ for $2 \mathrm{~h}$ before $20 \mu \mathrm{l}$ medium containing $500 \mathrm{ng} / \mathrm{ml}$ VEGF- $\mathrm{A}_{165}$ was added, resulting in a final concentration of $50 \mathrm{ng} / \mathrm{ml}$. Subsequently, CI was measured every 2 min for $1 \mathrm{~h}$ and then every 5 or $15 \mathrm{~min}$ for additional 48 to $72 \mathrm{~h}$ of cultivation. At the end of each experiment, the integrity of the iBREC monolayer was verified microscopically. In some experiments, serum-free culture medium was used instead of SRM. Recorded CI values were normalized in relation to those measured immediately before addition of inhibitors or VEGF-A ${ }_{165}$ (RTCA Software 2.0) and the results were converted to graphs showing means and standard deviation using Graph Pad Prism 6 (Graph Pad Software, San Diego, USA).

\section{Statistical analyses}

Mann-Whitney tests or one way analyses of variance (ANOVA) followed by Tukey's test to determine differing groups were used to compare measured CI values at selected time points (Graph Pad Prism 6) or quantified antigen-specific signals of Western blot analyses. Differences resulting in p-values below 0.05 were considered significant. In addition to providing means and corresponding standard deviations, results were presented as conventional box-whiskers diagrams showing means, percentiles $(75 \%, 25 \%)$ and the lowest/highest values or as scatter plots showing means and standard deviations.

\section{Results}

\section{General considerations}

iBREC were cultivated in the presence of physiologically relevant $100 \mathrm{nM}$ $11 \beta$-hydroxycortisone to ensure a stable expression of TJ proteins [8]. Unless mentioned otherwise cells had been kept for $24 \mathrm{~h}$ in culture medium with $0.25 \%$ FBS before effectors, i.e. inhibitors or VEGF-A ${ }_{165}$, were added to minimize potential effects of serum components on intracellular signaling. Serum starvation was avoided as this might have resulted in intracellular protein degradation and undesirable effects on vesicle formation. 


\section{Cellular Physiology Cell Physiol Biochem 2017;42:1493-1513 \\ \begin{tabular}{ll|l} 
and Biochemistry $10.1159 / 000479213$ & $\begin{array}{l}\text { (c) } 2017 \text { The Author(s). Published by S. Karger AG, Basel } \\
\text { www.karger.com/cpb }\end{array}$ \\
\cline { 2 - 3 }
\end{tabular} \\ Deissler et al.: Redundant VEGF-A Signaling Pathways Regulating Permeability of Retinal Endothelial Cells}

\section{iBREC rapidly internalized VEGF- $A_{165}$}

Confluent iBREC do not express amounts of VEGF-A detectable by Western blot analyses [8]. This observation was again confirmed by analyses performed with the more sensitive method ELISA (Fig. 1A; $t=0$ h or Fig. $3 \mathrm{C}$ ). The antibodies used in this assay recognize human, bovine and canine VEGF-A, but interaction of VEGF-A with its receptors might interfere. We detected VEGF-A in protein samples containing cytoplasmic proteins or proteins from membranes or organelles, respectively, which had been prepared after only 15 min of exposure of iBREC to $50 \mathrm{ng} / \mathrm{ml}$ (human) VEGF- ${ }_{165}$, indicating rapid internalization of this growth factor by these cells (Fig. 1A). The intracellular concentration of VEGF-A decreased over the next $3 \mathrm{~h}$, but was then more or less stable during prolonged exposure up to $24 \mathrm{~h}$.

\section{VEGF-A $A_{165}$ induced iBREC barrier disturbance in two distinct phases}

To evaluate the effect of VEGF-A ${ }_{165}$ on the barrier formed by an iBREC monolayer, the impedance of cells grown on gold electrodes was measured continuously throughout the experiment without interfering with the culture. The unit free parameter cell index (CI),

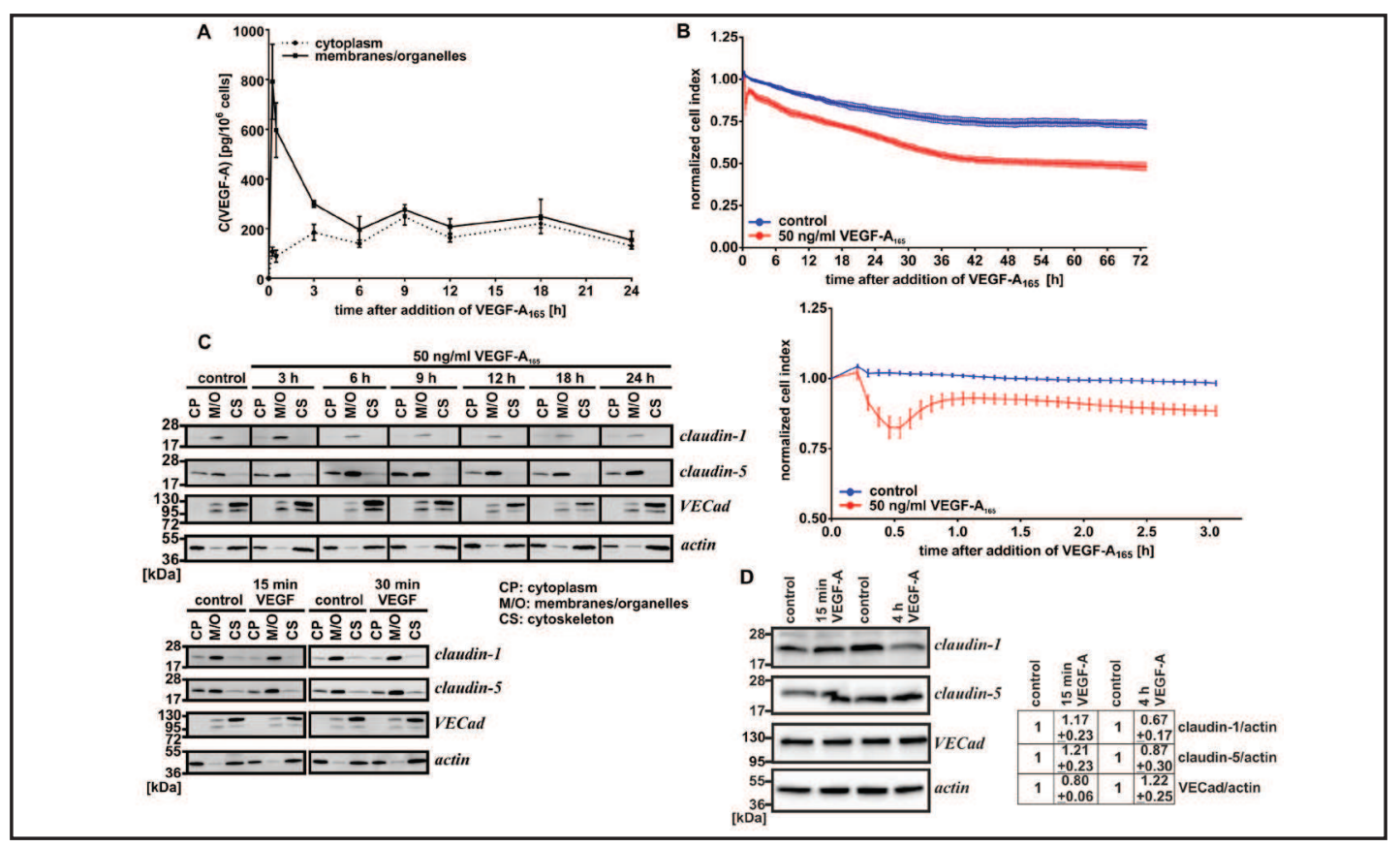

Fig. 1. Sustained reduction of CI of an iBREC monolayer caused by VEGF- $A_{165}$ correlated with loss of TJ

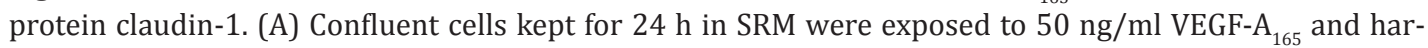
vested at indicated time points to prepare subcellular fractions. In these, VEGF-A was determined by ELISA as described in Materials and Methods. Confluent iBREC did not express VEGF-A ( $\mathrm{t}=0 \mathrm{~h}$ ), but after exposure to the growth factor considerable amounts were detected in subcellular fractions consisting of membrane/ organelle proteins or cytosolic proteins, respectively. (B-D) After cultivation in SRM, iBREC were exposed to

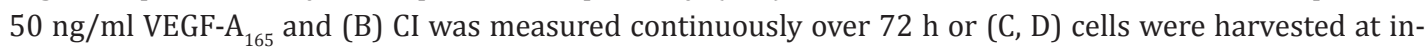
dicated time points for preparation of (C) subcellular fractions or (D) whole cell extracts, respectively. (B) VEGF- $A_{165}$ induced a sharp drop of the CI within 20 min after its addition, followed by fast recovery to only slightly lowered CI values, which then further decreased steadily. This pattern was also observed in the absence of FBS. CI values were normalized in relation to those measured immediately before addition of VEGF- $A_{165^{\circ}}$ (C) About $6 \mathrm{~h}$ after addition of VEGF- $A_{165}$, expression of the TJ protein claudin- 1 started to decline. Other proteins tested were not obviously affected. (D) Treatment of iBREC with VEGF-A $\mathrm{A}_{165}$ for $4 \mathrm{~h}$ but not for 15 min reduced the amount of TJ protein claudin- 1 whereas levels of claudin- 5 or VECad remained stable within the range of interexperimental deviations. Chemiluminescence signals were quantified and normalized to those of actin as described in Materials and Methods. 


\section{Cellular Physiology Cell Physiol Biochem 2017;42:1493-1513 \begin{tabular}{ll|l} 
DOI: 10.1159/000479213 & (O) 2017 The Author(s). Published by S. Karger AG, Basel
\end{tabular} \begin{tabular}{l|l} 
Published onlıne: July 18, $2017 \quad$ www.karger.com/cp \\
\hline
\end{tabular} \\ Deissler et al.: Redundant VEGF-A Signaling Pathways Regulating Permeability of Retinal Endothelial Cells}

calculated as described in Materials and Methods, is dependent on the number of cells, their morphology and adherence to the matrix, and a high CI correlates with a tight barrier of low permeability when confluent monolayers of cells are analyzed [26]. After cultivation for three to four days, a stable $\mathrm{CI} \sim 20$ reflected the formation of a confluent monolayer as verified by microscopy.

Exposure of an iBREC monolayer to $50 \mathrm{ng} / \mathrm{ml} \mathrm{VEGF-A}_{165}$ initially resulted in a significant decrease of the CI about $20 \mathrm{~min}$ after its addition, followed by a recovery phase and a sustained response several hours later, which lasted at least $3 \mathrm{~d}$ (Fig. 1B). The extent of the early transient response to VEGF- $A_{165}$ varied but the specific effect was highly significant in all experiments with $n=7$ replicates: Normalized CI values measured 20 min after addition of VEGF- $A_{165}$ were $0.825 \pm 0.036$ (versus control $1.019 \pm 0.006, \mathrm{p}<0.0001$ ) or $0.972 \pm 0.008$ (versus control $1.006 \pm 0.004, \mathrm{p}=0.0003$ ). A similar drop of $\mathrm{CI}$ was not observed when VEGF- $A_{165}$ was replaced by VEGF- $A_{165} b(50$ or $100 \mathrm{ng} / \mathrm{ml}$ ), a splice variant which differs only in the last $6 C$-terminal amino acids (data not shown) [48]. In accordance with previous studies, $10 \mu \mathrm{g} / \mathrm{ml}$ VEGF-A-binding Fab fragment ranibizumab completely prevented both early and delayed CI declines induced by VEGF- $\mathrm{A}_{165}$ (Fig. 5A). To examine whether $\mathrm{CI}$ values lowered by VEGF- $A_{165}$ correlated with compromised TJs, iBREC exposed to the growth factor were harvested at different time points for preparation of either whole cell extracts or subcellular fractions containing cytosolic proteins, proteins from membranes and organelles, and proteins of the cytoskeleton, respectively. In these, we determined the TJ protein claudin- 1 as a marker for TJ integrity and a functional barrier, indicated by a strong correlation between its expression and a high TER of iBREC or huREC monolayers [7-11, 46]. Decreased amounts of claudin-1 - co-extracted with membrane proteins or in whole cell extracts - were seen as early as four to $6 \mathrm{~h}$ after addition of VEGF-A ${ }_{165}$, but expression of claudin-5 or VECad were not obviously affected (Fig. 1C, D). Loss of claudin-1 with sustained presence of claudin-5 and VECad was confirmed by analyses of cells harvested $9 \mathrm{~h}, 12 \mathrm{~h}, 18 \mathrm{~h}, 24 \mathrm{~h}$ and $48 \mathrm{~h}$ after addition of VEGF- $\mathrm{A}_{165}$ (Fig. 1C, data not shown). Exposure for only 15 or 30 min to VEGF-A $\mathrm{A}_{165}$ was too short to affect the amount of claudin-1 or any other protein analyzed (Fig. 1C, D). However, translocation of VECad from the plasma membrane to intracellular organelles potentially induced shortly after exposure to VEGF- $A_{165}$ could not be ruled out based on the results of our experiments, because proteins of membranes and organelles were co-purified and undistinguishable in one of the protein fractions. At about $1 \mathrm{~h}$ after addition of VEGF- $\mathrm{A}_{165}$, the usually strong and uniform VECad-specific staining at the plasma membrane changed to a more uneven and interrupted distribution of the immunofluorescence signal also observed after prolonged exposure to the growth factor (data not shown; Fig. 2C). Expression and localization of caveolin-1 - a protein involved in transcytosis and transcellular flow - were not changed over the whole observation period ( $15 \mathrm{~min}$ to $24 \mathrm{~h}$ after addition of VEGF-A). Taken together, our findings strongly suggest that the delayed but sustained response of iBREC to the growth factor is associated with an altered composition of TJs then deficient of claudin-1. Therefore, we determined claudin-1 in our experiments as an additional marker indicative of a tight iBREC barrier.

Inhibition of VEGFR2 by ZM323881 prevented VEGF-A $A_{165}$-induced disturbance of an iBREC barrier

Pre-treatment of iBREC with $\leq 10 \mathrm{nM}$ tivozanib (alternative names: KRN951 or AV-951), an inhibitor of both VEGFR1 $\left(\mathrm{IC}_{50}=30 \mathrm{nM}\right)$ and VEGFR2 $\left(\mathrm{IC}_{50}=6.5 \mathrm{nM}\right)$, prevents VEGF- $A_{165}$-induced reduction of TER and of claudin-1 expression as assessed $24 \mathrm{~h}$ after addition of the growth factor to confluent iBREC $[8,39]$. To determine whether tivozanib blocked acute and sustained response of iBREC to VEGF-A ${ }_{165}$, CI measurements were performed. In these, tivozanib could be used at concentrations in the range of $10-100 \mathrm{nM}$, which did not affect barrier properties of iBREC over $48 \mathrm{~h}$, whereas higher amounts resulted in a barrier disturbance by the inhibitor itself (Fig. 2A). Both the early, transient decrease of $\mathrm{CI}$ as well as the later long-term response to VEGF- $\mathrm{A}_{165}$ were prevented completely when iBREC had been pre-treated with well-tolerated $10 \mathrm{nM}$ or $100 \mathrm{nM}$ tivozanib for $2 \mathrm{~h}$ (Fig. 2B, 


\section{Cellular Physiology \\ Cell Physiol Biochem 2017;42:1493-1513 and Biochemistry
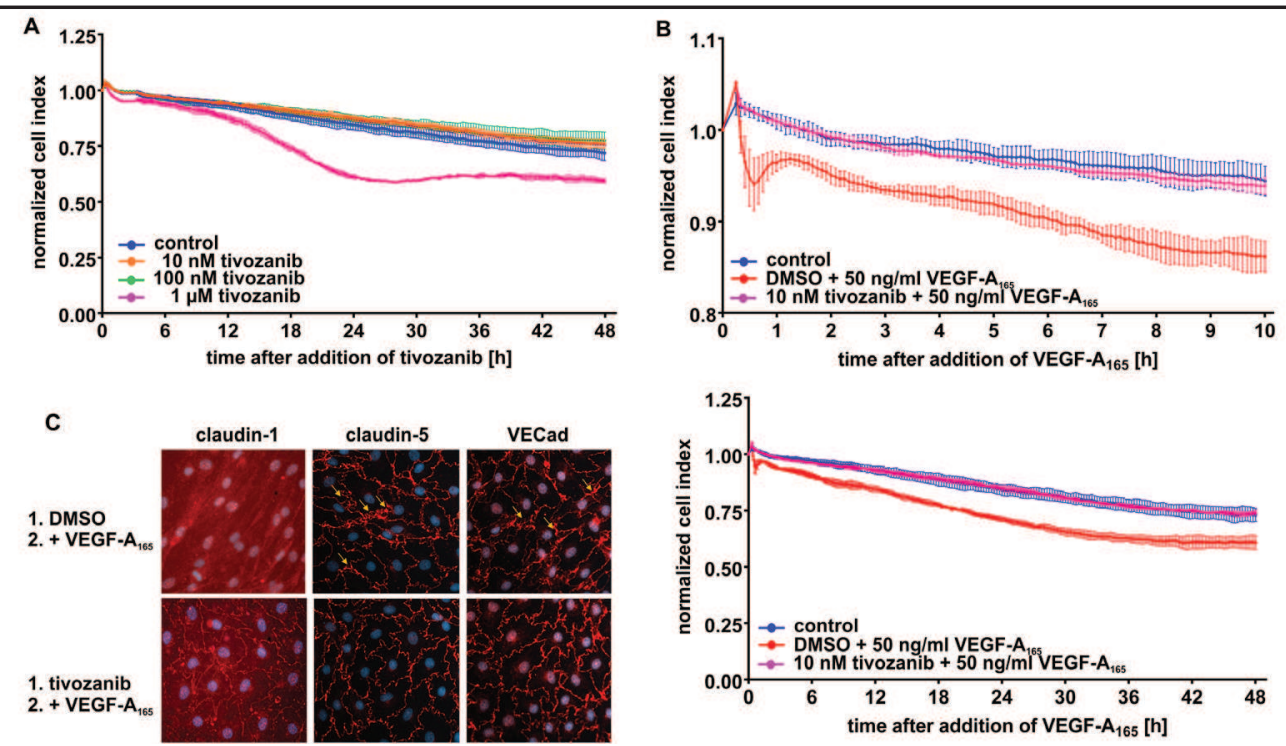

Fig. 2. Tivozanib, inhibitor of the VEGFRs, completely prevented both early transient and late sustained responses of iBREC to VEGF-A ${ }_{165}$ (A) iBREC were kept in SRM for $24 \mathrm{~h}$ before tivozanib was added and CI was monitored for $48 \mathrm{~h}$. At concentrations of $10 \mathrm{nM}$ or $100 \mathrm{nM}$, tivozanib did not affect the CI, whereas $1 \mu \mathrm{M}$ tivozanib led to a substantially decreased CI. (B) VEGF-A ${ }_{165}$ was added to iBREC treated as described in (A) for $2 \mathrm{~h}$ with $10 \mathrm{nM}$ tivozanib. Short- and long-term effects of VEGF-A ${ }_{165}$ were completely blocked. CI values were normalized in relation to those measured immediately before addition of VEGF- $A_{165^{\circ}}$ (C) Confluent iBREC were treated as described above and localizations of TJ proteins claudin- 1 and claudin- 5 as well as of AJ protein VECad were assessed by immunofluorescence staining. Tivozanib at $10 \mathrm{nM}$ completely prevented VEGF- $_{165}$-induced disappearance of plasma membrane staining specific for claudin-1. Treatment of iBREC with VEGF-A $A_{165}$ resulted in uneven and interrupted plasma membrane stainings (yellow arrows) of VECad and claudin- 5 also averted by pre-treatment with $10 \mathrm{nM}$ tivozanib.

Table 3). Pre-treatment with $10 \mathrm{nM}$ tivozanib also fully averted loss of claudin-1 localized in the plasma membrane and normalized the uneven and interrupted plasma membrane staining of claudin-5 or VECad caused by VEGF-A ${ }_{165}$ (Fig. 2C).

The still effective 10 nM tivozanib most likely only blocked VEGFR2 but not VEGFR1 or other receptor tyrosine kinases (see Table 1), suggesting a crucial role of VEGFR2 in induction and maintenance of a dysfunctional iBREC barrier. To further support this hypothesis, we included in our investigations of the barrier dysfunction induced by VEGF-A ${ }_{165}$ the VEGFR2specific inhibitor ZM323881, which inhibits tyrosine phosphorylation of VEGFR2 at $\sim 2$ $\mathrm{nM}$ and phosphorylation of VEGFR1 at $>50 \mu \mathrm{M}$, respectively [43]. ZM323881 was also well tolerated by iBREC that were treated for up to $60 \mathrm{~h}$ with 20 to $500 \mathrm{nM}$ of this inhibitor without observing any effect on CI or expression of claudin-1. When iBREC had been pretreated with $200 \mathrm{nM}$ or $500 \mathrm{nM}$ ZM323881 for $2 \mathrm{~h}$, the acute response to VEGF-A ${ }_{165}$ was completely blocked and the later, sustained CI reduction was at least prevented for several hours (Fig. 3A). Accordingly, expression of claudin-1 assessed after $22 \mathrm{~h}$ was not lowered

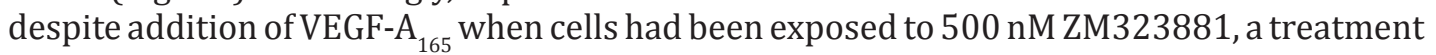
as effective as $10 \mathrm{nM}$ tivozanib in this respect (Fig. 3B). Similar to the effects of tivozanib, ZM323881 also averted VEGF-A-induced delocalization of claudin-1, claudin-5 and VECad (data not shown). In addition, inhibition of the VEGF receptors with ZM323881 or tivozanib did not change the amount of internalized VEGF- $\mathrm{A}_{165}$ as measured in whole cell extracts by ELISA (Fig. 3C). The limited duration of inhibition of VEGF-A-induced barrier malfunction by ZM323881 could be caused by instability of the drug or by decreasing relevance of VEGFR2 during prolonged exposure to the growth factor. Therefore, iBREC were pre-treated for $2 \mathrm{~h}$ with $200 \mathrm{nM}$ (or $500 \mathrm{nM}$ ) ZM323881 followed by incubation with VEGF-A ${ }_{165}$ for $24 \mathrm{~h}$ before 


\section{Cellular Physiology \\ Cell Physiol Biochem 2017;42:1493-1513 \\ \begin{tabular}{ll} 
DOI: 10.1159/000479213 & $\begin{array}{l}\text { C) } 2017 \text { The Author(s). Published by S. Karger AG, Base } \\
\text { www.karger.com/cpb }\end{array}$ \\
\cline { 2 - 4 }
\end{tabular} \\ Deissler et al.: Redundant VEGF-A Signaling Pathways Regulating Permeability of Retinal Endothelial Cells}

Fig. 3. ZM323881 - specific inhibitor of VEGFR2 - blocked early and late responses of iBREC to VEGF-A ${ }_{165}$. iBREC were treated with $200 \mathrm{nM}$ or 500 nM ZM323881 for $2 \mathrm{~h}$ before VEGF-A 165 was added and (A) CI was monitored for $48 \mathrm{~h}$ or (B) cells were harvested $22 \mathrm{~h}$ later to prepare protein extracts. (A) Depending on its concentration, ZM323881 prevented reduction of CI for several hours.

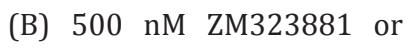
$10 \mathrm{nM}$ tivozanib completely averted VEGF-A $A_{165}$-induced loss of claudin-1 as assessed by Western blot analyses including proof of statistical significance after quantification and normalization of the signals as described in Materials and Methods. (C) Intracellular VEGF-A levels, determined by ELISA, were not affected by inhibition of VEGFR2 ( $*$ p $>0.05$ for VEGF$\mathrm{A}_{165} \pm$ inhibitors compared to control). (D) A second dose of ZM323881 (final concentration: $200 \mathrm{nM}$ ) was added to

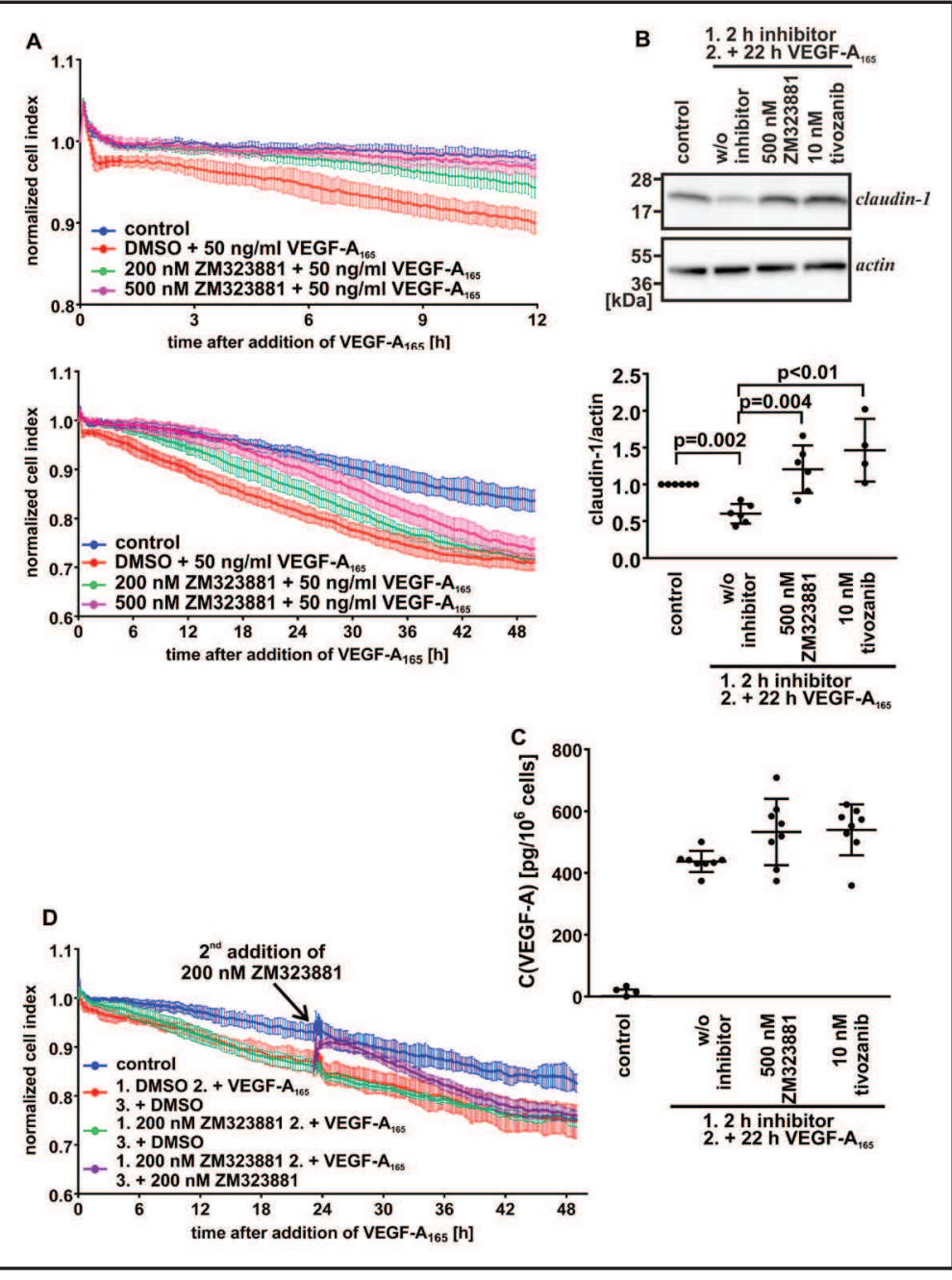
iBREC treated with VEGF-A ${ }_{165}$ and 200 nM ZM323881 for $24 \mathrm{~h}$ as described in (A). This normalized the CI, but only for several hours. CI values were normalized in relation to those measured immediately before addition of VEGF-A ${ }_{165}$.

more ZM323881 was added to restore the potentially degraded substance to the initial concentration. In accordance with an assumed limited stability of ZM323881, the lowered CI very quickly reached normal values in the presence of fresh inhibitor but decreased again after a few hours of further incubation (Fig. 3D).

Inhibition of eNOS by L-NAME enhanced the early response to VEGF- $A_{165}$

VEGF-A stimulates the generation of NO in REC and inhibition of eNOS by L-NAME increased albumin permeability of primary BREC shortly after exposure to VEGF-A ${ }_{165}$ [21]. In accordance with this observation, $200 \mathrm{nM}$ L-NAME - without affecting the unchallenged barrier - slightly enhanced the early CI drop of iBREC induced by VEGF-A ${ }_{165}$ and contributed to the overall effect over several hours (Fig. 4A). However, VEGF-A-induced down-regulation of claudin-1 was not more pronounced in the presence of $200 \mathrm{nM}$ L-NAME (Fig. 4B).

Blocking of various kinases activated through ligand-induced VEGF receptor signaling did not prevent barrier disturbance

To identify the protein kinases predominantly involved in VEGF-A $\mathrm{A}_{165}$-induced barrier weakening, we first tested effects of various inhibitors specific for protein kinases known to be activated early after binding of VEGF- $\mathrm{A}_{165}$ to the receptors VEGFR1/2. In all experiments, 


\section{Cellular Physiology \\ Cell Physiol Biochem 2017;42:1493-1513 \\ \begin{tabular}{ll|l}
\cline { 2 - 2 } and Biochem 10.1159/000479213 & $\begin{array}{l}\text { ( ) 2017 The Author(s). Published by S. Karger AG, Basel } \\
\text { www.karger.com/cpb }\end{array}$ \\
\hline
\end{tabular} \\ Deissler et al.: Redundant VEGF-A Signaling Pathways Regulating Permeability of Retinal Endothelial Cells}

Table 2. Effects of inhibitors on the unchallenged iBREC barrier. Confluent iBREC were exposed to the drugs at indicated concentrations and $\mathrm{CI}$ was measured continuously. To assess expression of claudin-1, cells were harvested after $24 \mathrm{~h}$. ND not done, $\downarrow / \downarrow \downarrow$ (strong) decrease, $\uparrow$ increase

Table 3. Effects of inhibitors on VEGF-A 165 -induced disruption of the iBREC barrier. Confluent iBREC were exposed to the drugs at indicated concentrations for $2 \mathrm{~h}$ before $50 \mathrm{ng} / \mathrm{ml}$ VEGF-A ${ }_{165}$ was added. CI was then measured continuously or cells were harvested $24 \mathrm{~h}$ later to prepare extracts for claudin-1 analyses. NA not applicable, ND not done

\begin{tabular}{|c|c|c|c|c|}
\hline \multirow{3}{*}{$\begin{array}{l}\text { Targeted protein } \\
\text { VEGFR1/2 }\end{array}$} & Inhibitor & Concentration(s) & Effect on $\mathrm{CI}$ ? & $\begin{array}{c}\text { Effect on claudin-1 } \\
\text { expression? }\end{array}$ \\
\hline & Tivozanib & $1 \mu \mathrm{M}$ & $\downarrow$ & ND \\
\hline & & $10,100 \mathrm{nM}$ & None & None \\
\hline VEGFR2 & ZM323881 & $20,200,500 \mathrm{nM}$ & None & None \\
\hline PLC & U73122 & $10,100,1000 \mathrm{nM}$ & None & None $(10 \mathrm{nM})$ \\
\hline PKC & GF $109203 X$ & $1 \mu \mathrm{M}$ & None & None \\
\hline \multirow[t]{2}{*}{ MEK } & PD98059 & $10 \mu \mathrm{M}$ & $<24 \mathrm{~h} \downarrow,>36 \mathrm{~h} \uparrow$ & $\downarrow$ \\
\hline & & $1 \mu \mathrm{M}$ & $\uparrow$ & $\uparrow$ \\
\hline \multirow[t]{3}{*}{ Src } & PP2 & $1 \mu \mathrm{M}$ & $\downarrow$ & None \\
\hline & & $10,100 \mathrm{nM}$ & None & None \\
\hline & Saracatinib & $10,100 \mathrm{nM}$ & None & None (10 nM) \\
\hline \multirow[t]{5}{*}{ PI3K } & Wortmannin & $100 \mathrm{nM}$ & None & None \\
\hline & LY294002 & $5 \mu \mathrm{M}$ & $\downarrow$ & $\downarrow$ \\
\hline & & $50,500 \mathrm{nM}$ & None & None \\
\hline & PI-103 & $0.5-5 \mu \mathrm{M}$ & $\downarrow \downarrow$ & ND \\
\hline & & $50 \mathrm{nM}$ & None & None \\
\hline \multirow[t]{2}{*}{ р38МАРК } & SB202190 & $>1 \mu \mathrm{M}$ & $\downarrow$ & ND \\
\hline & & $10,100 \mathrm{nM}$ & None & None $(10 \mathrm{nM})$ \\
\hline \multirow[t]{2}{*}{ Akt1/2 } & Akti-1/2 & $5 \mu \mathrm{M}$ & $\downarrow$ & ND \\
\hline & & $50,500 \mathrm{nM}$ & None & None (50 nM) \\
\hline \multirow{2}{*}{ FAK } & PF-562271 & $1 \mu \mathrm{M}$ & $\downarrow$ & ND \\
\hline & & $1,10,100 \mathrm{nM}$ & None & ND \\
\hline \multirow{3}{*}{ ROCK1/2 } & Y27632 & $5 \mu \mathrm{M}$ & $\uparrow$ & $\uparrow$ \\
\hline & & $500 \mathrm{nM}$ & $\uparrow$ & ND \\
\hline & & $50 \mathrm{nM}$ & None & ND \\
\hline \multirow[t]{2}{*}{ JNK } & SP 600125 & $1 \mu \mathrm{M}$ & $\downarrow$ & ND \\
\hline & & $10,100 \mathrm{nM}$ & None & None $(10 \mathrm{nM})$ \\
\hline \multirow[t]{2}{*}{ PKA } & КT5720 & $500 \mathrm{nM}$ & $\downarrow$ & ND \\
\hline & & $5,50 \mathrm{nM}$ & None & None \\
\hline eNOS & L-NAME & $200 \mathrm{nM}, 200 \mu \mathrm{M}$ & None & ND \\
\hline Targeted protein & Inhibitor & Concentration(s) $\begin{array}{r}\text { Prev } \\
\text { induc }\end{array}$ & $\begin{array}{l}\text { ention of VEGF- } \\
\text { ed CI decrease? }\end{array}$ & $\begin{array}{l}\text { Prevention of VEGF- } \\
\text { caused loss of claudin-1? }\end{array}$ \\
\hline \multirow[t]{2}{*}{ VEGFR1/2 } & Tivozanib & $10,100 \mathrm{nM}$ & $\begin{array}{l}\text { s, completely } \\
\text { over } 72 \mathrm{~h}\end{array}$ & Yes \\
\hline & & $1 \mu \mathrm{M}$ & None & ND \\
\hline \multirow[t]{3}{*}{ VEGFR2 } & ZM323881 & $20 \mathrm{nM}$ & None & None \\
\hline & & $200 \mathrm{nM}$ & $\begin{array}{l}\text { s, transiently } \\
\text { ring first } 6 \mathrm{~h}\end{array}$ & None \\
\hline & & $500 \mathrm{nM}$ & $\begin{array}{l}\mathrm{s} \text {, transiently } \\
\text { ring first } 18 \mathrm{~h}\end{array}$ & Yes \\
\hline PLC & U73122 & 10 to $1000 \mathrm{nM}$ & None & None $(10 \mathrm{nM})$ \\
\hline \multirow[t]{2}{*}{ PKC } & GF $109203 X$ & $\begin{array}{r}\text { Ye } \\
\text { duri }\end{array}$ & $\begin{array}{l}\text { s, transiently } \\
\text { ng first } 45 \mathrm{~min} \text {, }\end{array}$ & NA \\
\hline & & & tly after $30 \mathrm{~h}$ & None \\
\hline \multirow[t]{2}{*}{ MEK } & PD98059 & $1 \mu \mathrm{M}$ & $\begin{array}{l}\text { es, delayed } \\
\text { after } 36 \mathrm{~h}\end{array}$ & None \\
\hline & & $10 \mu \mathrm{M}$ & None & None \\
\hline \multirow[t]{2}{*}{ Src } & PP2 & 10 to $1000 \mathrm{nM}$ & None & None \\
\hline & Saracatinib & $10,100 \mathrm{nM}$ & None & None $(10 \mathrm{nM})$ \\
\hline PI3K & Wortmannin & $100 \mathrm{nM}$ & None & None \\
\hline & LY294002 & $50,500 \mathrm{nM}$ & None & None \\
\hline & PI-103 & $50 \mathrm{nM}$ & None & None \\
\hline p38MAPK & SB202190 & 10 to $1000 \mathrm{nM}$ & None & None $(10 \mathrm{nM})$ \\
\hline Akt1/2 & Akti-1/2 & 50 to $5000 \mathrm{nM}$ & None & None $(50 \mathrm{nM})$ \\
\hline FAK & PF-562271 & 1 to $1000 \mathrm{nM}$ & None & ND \\
\hline ROCK1/2 & Y27632 & $0.5,5 \mu \mathrm{M}$ & None & None $(5 \mu \mathrm{M})$ \\
\hline JNK & SP 600125 & 10 to, $1000 \mathrm{nM}$ & None & None $(10 \mathrm{nM})$ \\
\hline PKA & KT5720 & 5 to $500 \mathrm{nM}$ & None & None \\
\hline eNOS & L-NAME & $200 \mathrm{nM}, 200 \mu \mathrm{M}$ & None & None \\
\hline
\end{tabular}

iBREC were pre-treated with the different inhibitors for $2 \mathrm{~h}$ to specifically block activities of certain protein kinases before VEGF- ${ }_{165}$ (final concentration: $50 \mathrm{ng} / \mathrm{ml}$ ) was added and $\mathrm{CI}$ was measured for up to $3 \mathrm{~d}$ (Fig. 5A). Expression of claudin- 1 was assessed by Western blot analyses of cell extracts prepared $24 \mathrm{~h}$ after addition of VEGF- $A_{165}$ (Fig. 5B). None of the inhibitors specific for Akt1/2 $\rightarrow 50$ or $500 \mathrm{nM}$ Akti-1/2), Src $(\rightarrow 10$ or $100 \mathrm{nM}$ PP2 or



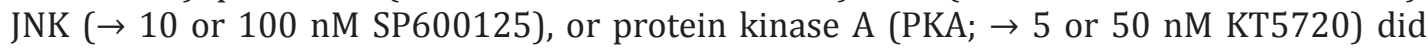
impede the acute and the late responses of iBREC to VEGF- $A_{165}$ (Fig. 5A; summarized in Table 3). Impaired barrier integrity despite treatment with these inhibitors was confirmed by loss of claudin-1 observed under these conditions (Fig. 5B; summarized in Table 3). At higher concentrations, most inhibitors not only did not prevent barrier destabilization by 


\section{Cellular Physiology Cell Physiol Biochem 2017;42:1493-1513 \begin{tabular}{c|c|c|} 
DOI: 10.1159/000479213 217 & $\begin{array}{l}\text { O } 2017 \text { The Author(s). Published by S. Karger AG, Basel } \\
\text { www.karger.com/cpb }\end{array}$
\end{tabular} \\ Deissler et al.: Redundant VEGF-A Signaling Pathways Regulating Permeability of Retinal Endothelial Cells}

Fig. 4. L-NAME - specific inhibitor of eNOS - enhanced the early response of iBREC to VEGF-A ${ }_{165}$. After treating iBREC with 200 nM L-NAME for $1 \mathrm{~h}$, $50 \mathrm{ng} / \mathrm{ml}$ VEGF-A was added and (A) CI was monitored for $24 \mathrm{~h}$ or (B) cells were harvested $1 \mathrm{~d}$ later to prepare cell extracts. (A) The early drop of CI induced by VEGF-A was slightly enhanced in the presence of L-NAME whereas the
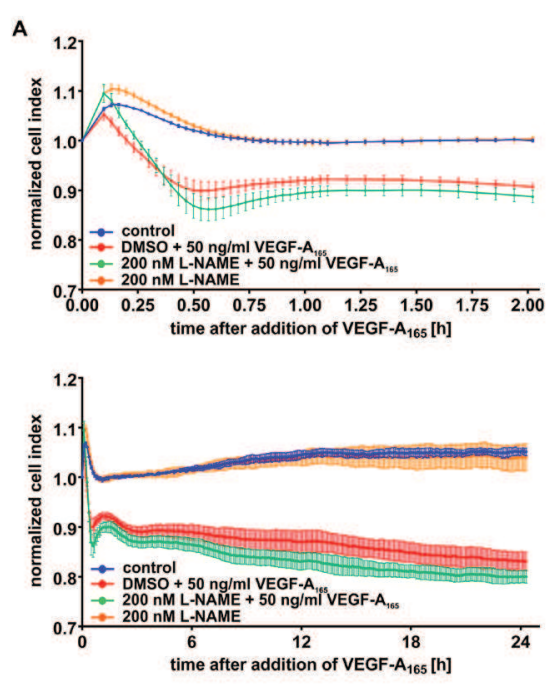

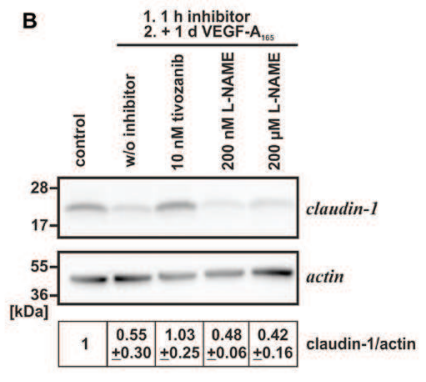

barrier of untreated iBREC was not influenced. CI values were normalized in relation to those measured immediately before addition of VEGF- $A_{165}$. (B) L-NAME did not counteract the VEGF-A-induced decrease of claudin-1. Chemiluminescence signals were quantified and normalized to actin as described in Materials and Methods.

Fig. 5. VEGF-A $A_{165}$-induced early and late responses of iBREC were not prevented by inhibition of various (protein) kinases or PLC. After pretreatment of confluent iBREC with single inhibitors for $2 \mathrm{~h}$, $50 \mathrm{ng} / \mathrm{ml}$ VEGF-A was added and (A) CI was measured or (B) cells were harvested $24 \mathrm{~h}$ later for subsequent analyses. (A) Single CI measurements performed

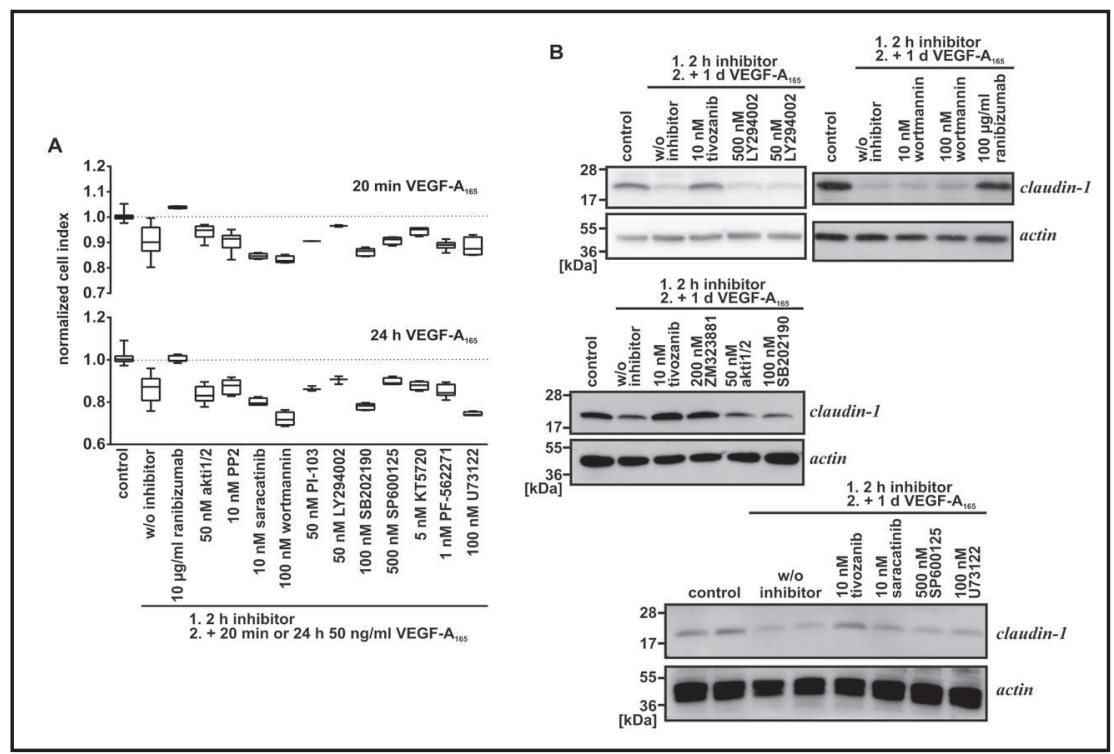
20 min (upper panel) or $24 \mathrm{~h}$ (lower panel) after addition of the growth factor are shown. To be able to compare different experiments, all values were normalized to control values for each time point. For both analyzed times of VEGF-A ${ }_{165}$ exposure, normalized CI values measured for control cells kept in SRM or cells treated with VEGF-A ${ }_{165}+$ ranibizumab were significantly higher than those of cells treated with VEGF-A $_{165} \pm$ inhibitors $(\mathrm{p}<0.05)$. Only the efficient control inhibitor ranibizumab - Fab-fragment binding to VEGF- $A_{165}$ - completely prevented early and late responses of iBREC, whereas other inhibitors tested did not have any significant effect. (B) Loss of claudin-1 induced by VEGF- $A_{165}$ was averted by ranibizumab, tivozanib or ZM323881, but not by any of the other inhibitors.

VEGF-A $A_{165}$ but even damaged the unchallenged iBREC barrier, typically accompanied by loss of claudin-1 (Tables 2 and 3). 


\section{Cellular Physiology Cell Physiol Biochem 2017;42:1493-1513 \\ \begin{tabular}{ll|l} 
and Biochemistry & Published online: July 18, 2017 & $\begin{array}{l}\text { () } 2017 \text { The Author(s). Published by S. Karger AG, Basel } \\
\text { www.karger.com/cpb }\end{array}$ \\
\cline { 2 - 4 }
\end{tabular} \\ Deissler et al.: Redundant VEGF-A Signaling Pathways Regulating Permeability of Retinal Endothelial Cells}

There is published evidence indicating that PI3K is involved in VEGF-A-caused disturbance of a barrier formed by macrovascular EC [20, 22]. However, effects of VEGF-A $A_{165}$ on CI or claudin-1 expression were not attenuated when microvascular iBREC had been pretreated with 50 or $500 \mathrm{nM} \mathrm{LY294002,} 50 \mathrm{nM}$ PI-103, or $100 \mathrm{nM}$ wortmannin (Fig. 5, Table 3). Increasing the concentrations of the PI3K-inhibitors PI-103 (to $0.5 \mu \mathrm{M}$ or $5 \mu \mathrm{M}$ ) or LY294002 (to $5 \mu \mathrm{M}$ ) resulted in a dramatic decrease of the CI even in the absence of VEGF- $\mathrm{A}_{165}$ and was accompanied by loss of claudin-1 (confirmed for $\geq 5 \mu \mathrm{M}$ LY294002), formation of vacuoles and eventually detachment of the cells (Table 2).

We also studied the effect of 73122 on the iBREC barrier because the PLC inhibited by this substanceis one of theimmediate downstream targets of theVEGFRsand hasbeen impliedinthe regulation of endothelial permeability [18]. However, U73122 at final concentrations of $10 \mathrm{nM}$, $100 \mathrm{nM}$ or even $1 \mu \mathrm{M}$ could not prevent the VEGF-A $\mathrm{A}_{165}$-induced decrease of CI measured over two days (Fig. 5).

Additionally, potential effects of ROCK inhibitor Y27632 on the iBREC barrier were investigated as this kinase was reported to play a role in the induction of permeability of coronary vessels by VEGF-A [23]. Although claudin-1 expression was slightly higher in iBREC treated with $5 \mu \mathrm{M}$ Y27632 for $1 \mathrm{~d}$, its VEGF-A-induced loss was still not prevented (Fig. 6A). Accordingly, CI was significantly higher during the first few hours of treatment with $0.5 \mu \mathrm{M}$ or $5 \mu \mathrm{M}$ Y27632 (Fig. 6B). This apparently barrier-stabilizing effect had to be taken into account in the analysis of data from experiments to reveal potential modulation of VEGFA's negative effects: After addition of VEGF- $A_{165}$ to iBREC pre-treated with $5 \mu \mathrm{M}$ Y27632 for $2 \mathrm{~h}$, decrease of the CI seemed to be delayed for several hours (Fig. 6B, C). However, when CI values were normalized in relation to those measured shortly before addition of VEGF- $\mathrm{A}_{165}$, pre-exposure to $5 \mu \mathrm{M}$ (or $0.5 \mu \mathrm{M}$ ) Y27632 did not result in significant differences, indicating that the ROCK inhibitor could also not neutralize VEGF- $\mathrm{A}_{165}$-induced barrier destabilization (Fig. 6D).

PKC-inhibitor GF $109203 X$ partly counteracted barrier disturbance only in certain phases during exposure of iBREC to VEGF-A $A_{165}$

Previous studies suggested that inhibiting PKC might prevent short-term, but not longterm responses of (i)BREC to VEGF- $A_{165}[7,25]$. To investigate further the still not entirely clear role of PKC, CI was measured continuously in single wells of the culture plates during long-term cultivation of iBREC. The cells were kept for $\sim 60 \mathrm{~h}$ in the presence of VEGF-A ${ }_{165}$ after having been treated for $2 \mathrm{~h}$ with $1 \mu \mathrm{M}$ GF $109203 \mathrm{X}$ which inhibits the PKC isoforms PKC $\alpha$, PKC $\beta I$, PKC $\beta I I$, and PKC $\gamma$ (Fig. 7A) [29]. GF 109203X did not affect the unchallenged iBREC barrier but blocked the early and transient effect of the growth factor, as observed during the first $45 \mathrm{~min}$ after its addition. Between $2 \mathrm{~h}$ and $12 \mathrm{~h}$ after addition of VEGF- $\mathrm{A}_{165}$, the CI curves of cells treated with VEGF-A $\mathrm{A}_{165}$ or with VEGF-A ${ }_{165}+$ GF $109203 \mathrm{X}$ were not different. At $\sim 18 \mathrm{~h}$ on the same time scale, the effect of VEGF-A ${ }_{165}$ on the GF 109203X-pre-treated cells was slightly but significantly diminished, although without complete normalization of $\mathrm{CI}$ values. This attenuation sustained at least for additional $36 \mathrm{~h}$. However, despite the partially regained CI-measured barrier integrity, loss of claudin- 1 was not prevented by PKC inhibition with GF 109203X (Fig. 7D) as previously described [7].

MEK inhibitor PD98059 blocked VEGF-A $A_{165}$-induced CI decrease after a lag phase

Experiments to study the effects of inhibition of MEK were included because it is further downstream of PKC in the signaling cascade initiated by binding of VEGF- $\mathrm{A}_{165}$ to its receptors. At a moderate concentration of $1 \mu \mathrm{M}$ PD98059, the MEK inhibitor stabilized the unchallenged iBREC barrier, indicated by higher CI values (Fig. 8A). When higher amounts were used, the $\mathrm{CI}$ was even lower than measured in control wells, although overall stabilization was seen during prolonged cultivation for several days (Fig. 8A). These observations strongly suggested using the inhibitor at a concentration of $1 \mu \mathrm{M}$ to evaluate whether inhibition of MEK affects VEGF- $A_{165}$-induced barrier weakening indicated by a decrease of CI. When iBREC had been pre-treated with PD98059 for $2 \mathrm{~h}$ before VEGF- $\mathrm{A}_{165}$ was added, the acute response was not 


\section{Cellular Physiology Cell Physiol Biochem 2017;42:1493-1513

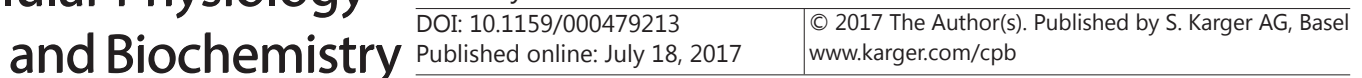 \\ Deissler et al.: Redundant VEGF-A Signaling Pathways Regulating Permeability of Retinal Endothelial Cells}
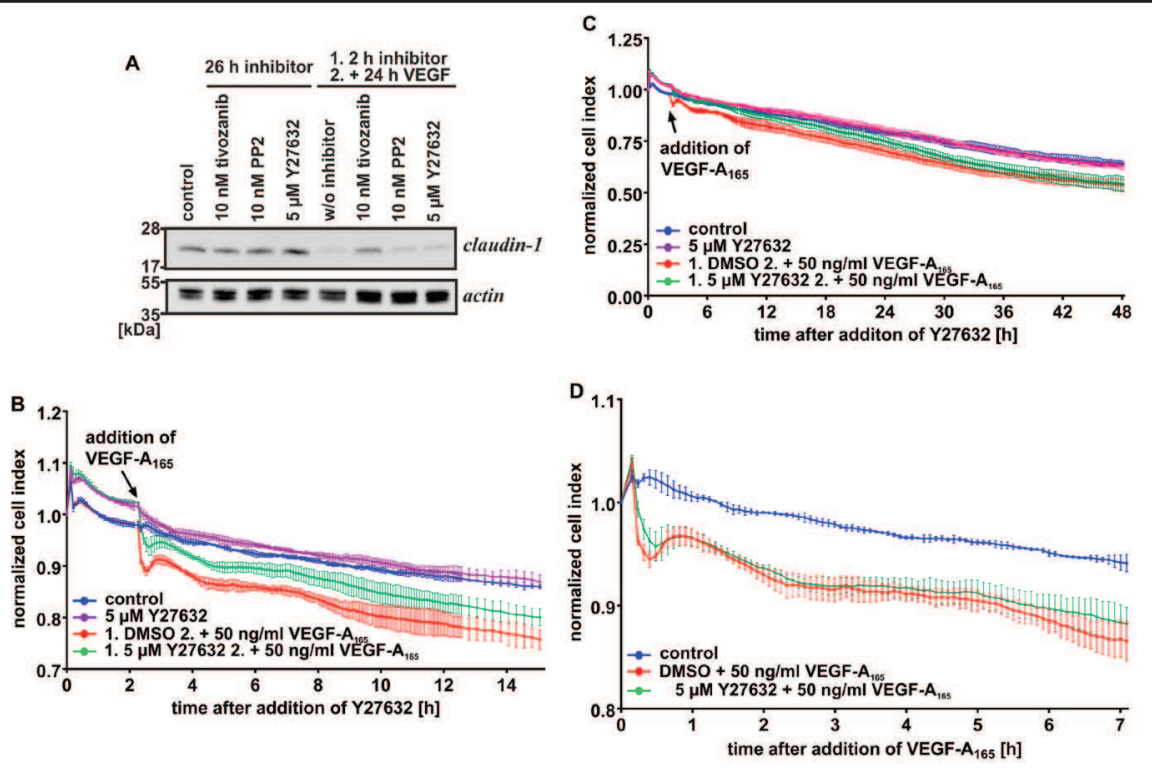

Fig. 6. Inhibition of ROCK by Y27632 stabilized the iBREC barrier but did not prevent VEGF-A $_{165}$-induced barrier disturbance. Confluent iBREC were pre-treated with Y27632 for $2 \mathrm{~h}$ before VEGF-A $_{165}$ was added and (A) cells were harvested $24 \mathrm{~h}$ later or (B-D) CI was measured. (A) Expression of claudin-1 assessed by Western blot analyses of cell extracts was slightly increased after treatment with $5 \mu$ M Y27632 but its VEGF- $A_{165}$-caused loss could not be prevented by the inhibitor. (B, C) Y27632 slightly increased CI of iBREC before and after addition of VEGF- $A_{165}$ as seen after normalization to those CI values measured before the inhibitor was added. (D) Normalization of CI values in relation to those measured before the addition of VEGF- $A_{165}$ revealed that Y27632 did not counteract barrier disturbance induced by the growth factor.

Fig. 7. $\mathrm{PKC}$-inhibitor GF 109203X suppressed only the early transient response of iBREC to VEGF-A ${ }_{165}$. (A) Confluent iBREC were pre-treated with the inhibitor of various PKC isoforms GF 109203X for $2 \mathrm{~h}$ before VEGF-A $A_{165}$ was added and CI was measured over more than $2 \mathrm{~d}$. Drop of CI induced by VEGF-A $_{165} 20$ min after its addition was completely blocked whereas its long-term
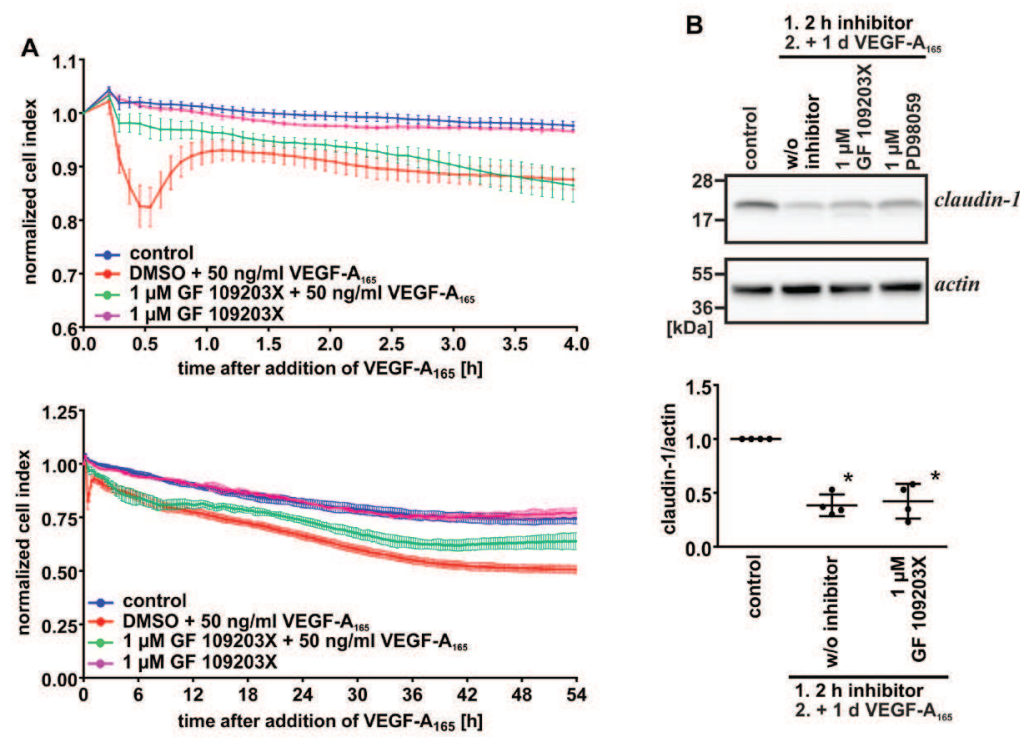
effect was only partly inhibited. (B) After cultivation in SRM for $24 \mathrm{~h}$, iBREC were treated with $1 \mu \mathrm{M}$ GF 109203X or $1 \mu \mathrm{M}$ PD98059 for $2 \mathrm{~h}$ before $50 \mathrm{ng} / \mathrm{ml} \mathrm{VEGF-A}_{165}$ was added. Cells were harvested $24 \mathrm{~h}$ later for preparation of cell extracts, and claudin-1 was assessed by Western blot. Resulting specific signals were quantified as described in Materials and Methods. Inhibition of PKC did not prevent loss of claudin-1 ( ${ }^{*} \mathrm{p}<0.01$ for VEGF- $\mathrm{A}_{165} \pm$ inhibitors compared to control). 


\section{Cellular Physiology \\ Cell Physiol Biochem 2017;42:1493-1513 and Biochemistry \begin{tabular}{l|l}
\hline DOI: 10.1159/000479213 & C 2017 The Author(s). Published by S. Karger AG, Basel
\end{tabular} www.karger.com/cpb \\ Deissler et al.: Redundant VEGF-A Signaling Pathways Regulating Permeability of Retinal Endothelial Cells}

Fig. 8. MEK-inhibitor PD98059 affected iBREC's late response to VEGF-A ${ }_{165}$ (A) iBREC were kept in SRM for $24 \mathrm{~h}$ before PD98059 was added and $\mathrm{CI}$ was monitored for $>60 \mathrm{~h}$. At lower concentrations, PD98059 permanently stabilized the unchallenged barrier, whereas higher amounts resulted in a transiently decreased CI. (B) Cells were treated as described in (A) for $2 \mathrm{~h}$ with $1 \mu \mathrm{M}$ PD98059


early response of iBREC to VEGF- $A_{165}$ was not blocked, but the CI of cells pre-treated with PD98059 recovered towards control values. Similar results were observed when iBREC had been cultivated in absence of FBS. CI values were normalized in relation to those measured immediately before addition of (A) PD98059 or (B) VEGF-A ${ }_{165^{*}}$ (C) After cultivation in SRM for $24 \mathrm{~h}$, iBREC were treated with $1 \mu \mathrm{M}$ PD98059 for $2 \mathrm{~h}$ before $50 \mathrm{ng} / \mathrm{ml}$ VEGF- $_{165}$ was added. Cells were harvested one or three days later and whole cell extracts were prepared. Claudin-1 was assessed by Western blot and resulting specific chemiluminescence signals were normalized to those of actin as described in Materials and Methods. More claudin-1 was expressed after exposure of the cells to $1 \mu \mathrm{M}$ PD98059 for one day, but not for three days $\left(^{*} \mathrm{p}<0.01\right.$ compared to control). Typical VEGF- $\mathrm{A}_{165}$-induced loss of claudin-1 was observed despite
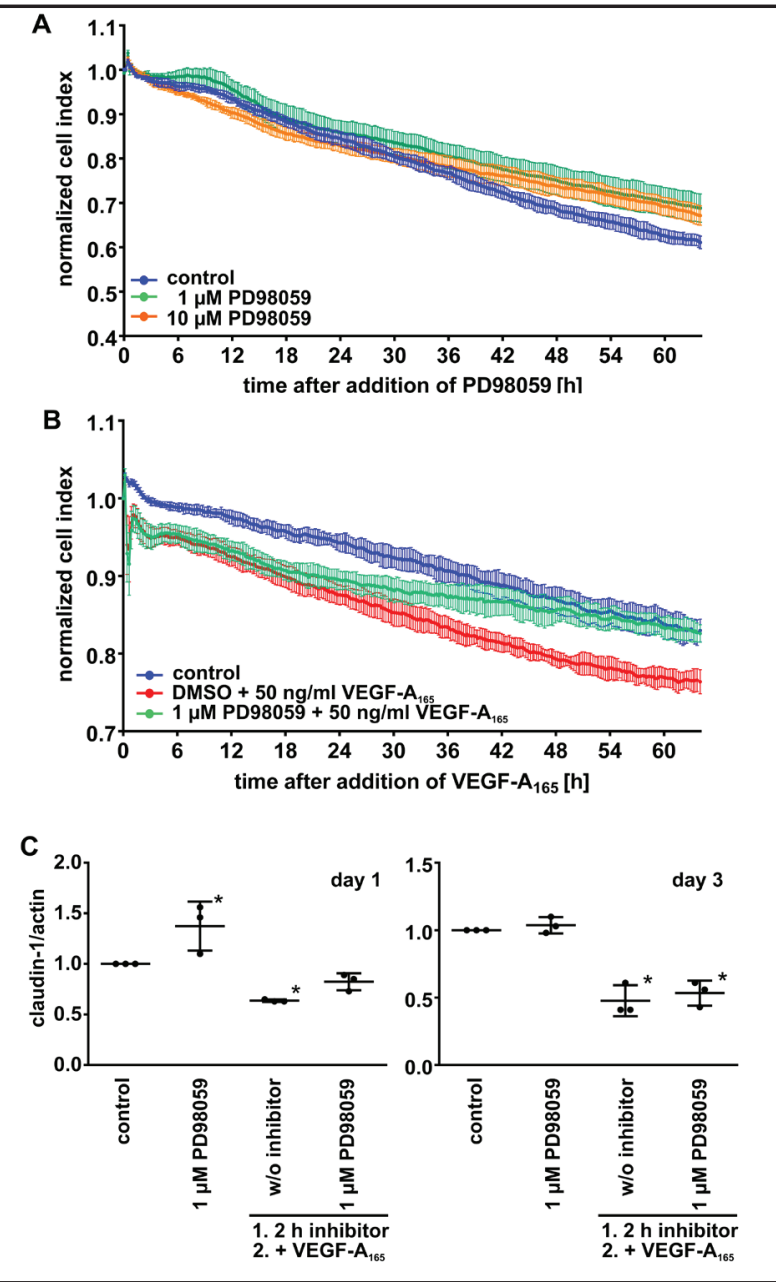

MEK inhibition $\left({ }^{*} \mathrm{p}<0.01\right.$ for VEGF-A $\mathrm{A}_{165} \pm$ inhibitors compared to control).

changed (Fig. 8B) even under serum-free conditions. However, the CI strongly increased $\sim 30 \mathrm{~h}$ after addition of VEGF- $\mathrm{A}_{165}$ and reached control values several hours later when the cells had been exposed to $1 \mu$ M PD 98059 (Fig. 8B). Despite the positive effect of PD98059 on CI-measured barrier integrity, the VEGF- $A_{165}$-induced loss of claudin-1 was neither prevented nor reversed by treatment with this inhibitor as assessed by Western blot analyses 1 or $3 \mathrm{~d}$ after addition of effectors (Fig. 8C).

\section{Discussion}

VEGF-A-induced permeability of REC is considered the pathological hallmark of diabetic macular edema (DME) [1]. In accordance with a crucial role of this factor, VEGF-A depletion, e.g. with the VEGF-A-binding Fab fragment ranibizumab, and thereby preventing signaling through the receptors VEGFR1/2 is a widely used and successful therapeutic option [49]. To understand better VEGF-A signaling in REC, the most relevant target cell type in the eye concerning DME, we investigated whether inhibition of key signaling proteins by specific inhibitors is sufficient to partially or completely suppress VEGF-A-induced disruption of a barrier formed by iBREC, a well-established cell line.

Here we confirmed our previous findings that confluent iBREC did not express detectable amounts of VEGF-A [8]. However, VEGF-A was isolated together with proteins from the plasma membrane, organelles and cytoplasm from iBREC that had only shortly 


\section{Cellular Physiology Cell Physiol Biochem 2017;42:1493-1513 and Biochemistry Published online: July 18, $2017 \quad \begin{gathered}\text { D 2017 The Authors. } \\ \text { www.karger.com/cpb }\end{gathered}$ \\ Deissler et al.: Redundant VEGF-A Signaling Pathways Regulating Permeability of Retinal Endothelial Cells}

been cultivated in medium containing the growth factor. At this early stage of exposure most of the added VEGF-A was probably bound to the VEGF receptor(s) at the cell surface, but most likely only free VEGF-A was measured because VEGFR1/2 present in the sample might interfere with binding of the detection antibodies of the ELISA system. Whether VEGF-A was taken up by iBREC in complex with its receptors is not clear, but this process seemed not to depend on activation of their tyrosine kinase domains because it was not affected by inhibition of VEGFR1/2. Interestingly, iBREC internalized VEGF- $A_{165}$ in the presence of ranibizumab (Deissler et al., unpublished observations), which prevents binding of the growth factor to its receptors, suggesting that VEGF-uptake could also be independent of VEGFR1/2.

Continuous CI measurements of iBREC grown on gold electrodes allowed observing the effects of the inhibitors on an unchallenged or VEGF- $\mathrm{A}_{165}$-disturbed barrier over several days without interfering otherwise. Detection of small or transient effects was thereby possible, in clear contrast to conventional TER measurements, which can only be performed at a limited number of defined time points [7-12, 26, 27]. Strikingly similar to effects observed in capillaries in vivo, VEGF-A $A_{165}$ induced a bi-phasic iBREC response: The CI dropped sharply shortly after addition of VEGF- $\mathrm{A}_{165}$ but soon recovered, before values started to decrease continuously a few hours later, resulting in a sustained $\mathrm{CI}$ reduction that lasted at least $3 \mathrm{~d}$ (see Fig. 2). The early transient response to VEGF-A - also observed in micro- or macrovascular endothelial cells of the bovine lung - might be due to a temporarily modified $\mathrm{Ca}^{2+}$ influx rather than to persistent changes of $\mathrm{TJ}$ compositions $[17,18,22]$. Our observation that inhibiting NO-synthesizing eNOS slightly enhanced the early response to VEGF-A suggests generation of ROS, NO and subsequently peroxynitrite by iBREC in this phase of exposure, in accordance with very similar results of experiments with primary BREC [21]. That knockout of eNOS accelerated the development of retinopathy in diabetic mice points to a substantial contribution of this pathway to pathogenic mechanisms in the retina [50]. The increased permeability initially seen during treatment with VEGF-A might partly also be due to internalization of the AJ protein VECad triggered by downstream signaling after FAK activation [13-15]. However, inhibition of FAK was not sufficient to prevent or inhibit early or late effects on iBREC suggesting potential bypassing of FAK in VEGF-initiated signaling. Nevertheless, it can be assumed that early changes of VECad's plasma membrane localization - observed during the first hours after addition of VEGF- $A_{165}$ - triggered derangement of AJ and TJ: During the late phase of iBREC's response to VEGF- $A_{165}$ claudin- 1 completely disappeared from the plasma membrane and part of VECad was internalized (Fig. 2C) [7-9, $13,14]$. Accordingly, enduring depletion of the TJ protein claudin-1, considered indicative of a dysfunctional barrier of huREC or iBREC, coincided with the phase of sustained low CI beginning about $6 \mathrm{~h}$ after addition of VEGF-A [7-11]. In contrast, expression and intracellular localization of caveolin, which is involved in transcellular flow through EC, were not changed, strongly suggesting that the observed REC barrier destabilization was established mainly by modification of the paracellular flow.

Inhibition of the VEGF receptor(s) with tivozanib completely prevented VEGF-Ainduced barrier disturbances when the inhibitor was used at a concentration slightly above

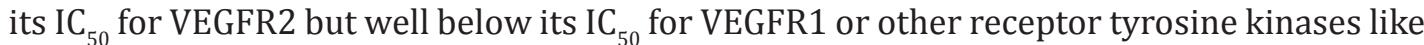
PDGFR $\alpha / \beta$ (see Fig. 3 and Table 1) [8, 39]. This suggested a predominant role of VEGFR2 in the branches of signal transduction triggered by VEGF- $A_{165}$ that are involved in the regulation of iBREC permeability. Strongly supporting this assumption, ZM323881 specifically blocking the activity of VEGFR2 without affecting other receptor tyrosine kinases also completely suppressed effects of VEGF- $A_{165}$ on the iBREC barrier over several hours [43]. Complete abrogation of the barrier effect of VEGF- $A_{165}$ was not observed over an extended time $(\geq 24$ h) of exposure but this most likely only reflected the limited stability of ZM323881 in cell culture medium (see Fig. 3D). From our experiments with inhibitors of the receptors, we conclude that activation of VEGFR2 by VEGF- $\mathrm{A}_{165}$ is mandatory for a lasting destabilization of the REC barrier, whereas the VEGFR1 appears to be less significant. This is in accordance with our previous findings that viral VEGF-E, which activates VEGFR2 and NRP-1 but not VEGFR1, 


\section{Cellular Physiology Cell Physiol Biochem 2017;42:1493-1513 \begin{tabular}{l|l}
\hline DOI: 10.1159/000479213 & (c) 2017 The Author(s). Published by S. Karger AG, Basel
\end{tabular} Published online: July 18, 2017 www.karger.com/cpb \\ Deissler et al.: Redundant VEGF-A Signaling Pathways Regulating Permeability of Retinal Endothelial Cells}

can lower the TER of iBREC and expression of claudin- 1 as efficiently as VEGF-A ${ }_{165}$ [9, 51]. In addition, Jeong et al. showed that the VEGF- $\mathrm{A}_{165}$-induced breakdown of a huREC barrier could also be prevented by apatinib, a substance preferentially inhibiting VEGFR2 kinase activity [14]. Although only short-term effects were assessed and inhibition of other protein kinases (e.g. Src) could not be ruled out at the concentrations used, the results of this investigation are in complete accordance with our findings, again confirming the highly similar behaviors of iBREC and huREC. Our results together with previous observations that VEGF-A-induced hyperpermeability of porcine coronary venules or frog mesenteric microvessels could be blocked by inhibition of VEGFR2, suggest that this is the pivotal receptor in the regulation of endothelial barrier function in microvessels of many tissues [17, 43].

The majority of the inhibitors tested in this study neither affected the unchallenged barrier of microvascular iBREC nor prevented VEGF- $\mathrm{A}_{165}$-induced early or late break-down of a barrier formed by these cells when used at concentrations close to published IC $_{50}$ values of the targeted kinases (summarized in Tables 2 and 3). Using such reasonable concentrations was of great importance because, in most cases, higher amounts resulted in a marked decrease of the CI often accompanied by loss of the TJ protein claudin- 1 , which clearly indicated a considerable disturbance of the iBREC barrier by the inhibitor itself (summarized in Table 2). This is a remarkable observation in view of high inhibitor concentrations used by other investigators who did not recognize any intrinsic barrier-damaging properties of these inhibitors. At concentrations well above the IC50 values, their observations, including reported anti-VEGF-A effects, might at least partly be due to unspecific activities of the substances $[19,20,22]$. In addition to moderate inhibitor concentrations, two other basic differences to other studies limit the degree to which our results can be compared: In contrast to homogenous iBREC, commonly used cultures of primary cells typically contain contaminating cells of other types, which may modulate barrier function and responses to VEGF-A or inhibitors that then might be required at higher concentrations. Furthermore, most of the related studies focused on macrovascular EC, e.g. HUVEC or bovine pulmonary arterial EC [19, 20,22]. Conflicting results may simply reflect different characteristics of EC from macro- and microvascular vessels defined by their varying gene expression profiles, which even differ between microvascular EC of the retina and the choroid [52].

Fundamental differences between species also have to be taken into consideration. Vascular permeability and associated expression of TJs are apparently regulated differently in rodents compared to larger mammals including man and cattle (Bos taurus): Src activation has been implied to be involved in the regulation of retinal vascular permeability in rodents, namely rabbits and mice in which topical administration of Src-inhibitor PP1 suppressed a barrier weakening in the retinal vessels induced by intravitreal injection of VEGF- $\mathrm{A}_{165}$. Accordingly, in mice deficient in $\mathrm{Src}\left(\mathrm{src}^{-1}\right)$ vascular leakage could not be induced by treatment with VEGF-A ${ }_{165}$ [53]. In contrast, inhibition of Src with the structurally related PP2 or with saracatinib did not prevent impairment of an iBREC barrier by VEGF- $A_{165}$, as indicated by a lowered $\mathrm{CI}$ in all phases after its addition to the cells. This finding is in accordance with the observation that PP2 did not interfere with VEGF-A-induction of acute barrier dysfunctions of macro- or microvascular cells of the bovine lung [22]. Taking into account that VEGF- $A_{121}$ rather than VEGF- $A_{165}$ can activate Src in HUVEC and that VEGF- ${ }_{165}$ more efficiently disturbs the iBREC barrier compared to VEGF- $A_{121}$, it may be concluded that Src is not significantly involved in VEGF- $A_{165}$-triggered signaling leading to disturbances of barriers formed by human or bovine (retinal) EC $[9,54]$.

Variations in culture conditions (e.g. different media components) could account for conflicting results of in vitro studies concerning the effects of kinase inhibitors even when the same cell type was investigated. For instance, glucocorticoids generally stabilize the barrier of BREC in vitro by inducing expression of TJ proteins like claudin-5; dexamethasone prevented barrier destabilization of BREC caused by inflammatory cytokines [55, 56]. In addition, a number of serum components could activate various signaling pathways, whereas serum starvation of iBREC compromised the formation of early endosomes (expressing early endosome antigen 1) and thereby resulted in a modified transport of IgG [57]. Keeping 


\section{Cellular Physiology Cell Physiol Biochem 2017;42:1493-1513 \begin{tabular}{ll|l} 
DOI: 10.1159/000479213 & 2017 The Author(s). Published by S. Karger AG, Basel \\
\hline
\end{tabular} and Biochemistry Published online: July 18, 2017 www.karger.com/cpb \\ Deissler et al:: Redundant VEGF-A Signaling Pathways Regulating Permeability of Retinal Endothelial Cells}

adipocytes in medium without serum over a longer period ( $>24 \mathrm{~h}$ ) activated their ubiquitinproteasome system, accompanied by an increased sensitivity to insulin [58]. Considering such strong effects of experimental conditions, it is difficult to compare results of independent in vitro studies and even more so in view of often not published vital details. Accurately assessing barrier integrity and function of $\mathrm{EC}$ is also a critical aspect. The occasionally used measurement of IgG or albumin transport through an (retinal) EC barrier can easily lead to inconclusive results because of variable contributions of transcellular and paracellular flow. Both pathways are relevant under these conditions due to the active transport of IgG or albumin mediated by the receptor/transporter protein neonatal Fc receptor, of which substantial amounts are expressed by (retinal) EC [57, 59].

The mechanisms leading to our astonishing observation that some of the commonly used inhibitors even disturbed the unchallenged iBREC barrier are unclear but some reasonable assumptions can be made: Strong decrease of CI caused by the PI3K inhibitors LY294002 and PI-103 might be due to weaker adhesion of the cells to the growth surface including the gold electrodes. That inhibition of PI3K hindered adhesion of BREC to fibronectin or fragments thereof was shown previously [60]. In addition, large vacuole-like vesicles were observed in iBREC after treatment with PI-103, LY294002 or wortmannin, which most likely reflected an impaired formation of early endosomes as a consequence of PI3K inhibition [61]. These changes might lead to a decreased $\mathrm{CI}$ because it is dependent on cell morphology and strength of their adhesion. However, loss of claudin-1 induced by $\geq 5 \mu \mathrm{M}$ LY294002 also suggested a more direct disturbance of the iBREC barrier through modification of TJs. Summed up PI3K results strongly suggest that inhibition of this kinase leads to destabilization of the iBREC barrier. This is in contrast to findings based on experiments with macrovascular HUVEC, again confirming that EC from different tissues vary in their properties and behavior [20, 22]. Interestingly, we also observed a transient and reversible destabilization of the iBREC barrier, reflected by lowered CI and loss of claudin- 1 , in the presence of high concentration of the MEK-inhibitor PD98059 (10 $\mu$ M, see Fig. 8A). This might provide a rationale for the transient appearance of subretinal fluid in patients receiving systemic anti-cancer treatment with MEK inhibitors [62].

Continuous $\mathrm{CI}$ measurements allowed us to show in one and the same iBREC culture that inhibition of PKC completely prevented the early transient barrier disturbance by VEGF- $\mathrm{A}_{165}$ but only partly inhibited the later sustained response to the growth factor. This demonstration of clearly distinguishable phases of VEGF- $\mathrm{A}_{165}$ action and corresponding susceptibilities to interfering substances clarified previously reported contradictory observations concerning PKC inhibitors $[7,25]$. It also showed that from blocking the early response of (iB)REC to VEGF- $A_{165}$, complete prevention of its long-term effects cannot necessarily be concluded. In this context, it is of special interest that for treatment of DME the beneficial effect of the PKC $\beta$ inhibitor ruboxistaurin was very limited [63]. Interestingly, inhibition of MEK with PD98059 resulted in a delayed normalization of the VEFG- $\mathrm{A}_{165}$-induced barrier disturbance. PD98059 specifically and reversibly binds to the inactive form MEK1, thereby preventing its activation without directly affecting ERK or related MAPK-kinases like p38MAPK or JNK [34]. From our data, however, we concluded that MEK was not activated by VEGF- $\mathrm{A}_{165}$ during the early response of iBREC, but a delayed activation of this kinase during prolonged exposure could not be ruled out. Confirming the different behavior of macrovascular EC, the early and transient VEGF-A-induced barrier dysfunction of HUVEC was prevented by MEK inhibition; however, long-term effects were not investigated in this study [19].

Although we used the model of immortalized EC of the bovine retina and there is only a limited amount of confirming data based on experiments with primary human REC, we conclude that for the treatment of macular edema secondary to DR or RVO, either blockage of the VEGF receptor tyrosine kinase activities or combined inhibition of several signaling routes are likely more promising strategies than targeting only single kinases or pathways. However, potential detrimental effects of multi-targeting approaches on other ocular cell types have then to be considered. 


\section{Cellular Physiology Cell Physiol Biochem 2017;42:1493-1513 \\ \begin{tabular}{l|l} 
and Biochemistry Published online: July 18, 2017 & $\begin{array}{l}\text { O 2017 The Author(s). Published by S. Karger AG, Basel } \\
\text { www.karger.com/cpb }\end{array}$ \\
\cline { 2 - 3 }
\end{tabular} \\ Deissler et al.: Redundant VEGF-A Signaling Pathways Regulating Permeability of Retinal Endothelial Cells}

In summary, we verified our hypothesis that VEGF-A-initiated signaling is redundant and that therefore blocking key proteins of single pathways is not sufficient to suppress completely the VEGF-A-induced breakdown of a barrier consisting of REC. In addition, our results strongly support the assumption that short-term and long-term effects of VEGF- $A_{165}$ vary and that kinase inhibitors or other interfering substances may differently affect VEGF-A-triggered processes in these phases. This again emphasizes the importance of careful interpretation of preclinical findings based on the available in vitro and animal models, particularly when conclusions regarding the in vivo situation in patients are drawn.

\section{Acknowledgements}

This study was supported by a research grant provided by the Getrud Kusen Stiftung, Hamburg, Germany to Gerhard K. Lang. The funding source did not have any influence on study design, data analyses and interpretation, writing of the manuscript, and decision on publishing, whatsoever.

The authors thank Susanne Denning, Edith Glass, Nadine Gubernath, Anita Ruepp and Sarah Scislowski for expert technical assistance. They are also grateful to Helmut Deissler, Ulm, Germany for his advice and for supporting the preparation of the manuscript.

\section{Disclosure Statement}

There are no commercial interests to declare concerning data generated in this study.

\section{References}

1 Qaum T, Xu Q Joussen AM, Clemens MW, Qin W, Miyamoto K, Hassessian H, Wiegand SJ, Rudge J, Yancopoulos GD, Adamis AP: VEGF-initiated blood-retinal barrier breakdown in early diabetes. Invest Ophthalmol Vis Sci 2001;42:2408-2413.

-2 Ozaki H, Yu AY, Della N, Ozaki K, Luna DJ, Yamada H, Hackett SF, Okamoto N, Zack DF, Semenzy GL, Campochiaro PA: Hypoxia inducible factor-1alpha is increased in ischemic retina: temporal and spatial correlation with VEGF expression. Invest Ophthalmol Vis Sci 1999;40:182-189.

-3 Aiello LP, Avery RL, Arrigg PG, Keyt BA, Jampel HD, Shah ST, Pasquale LR, Thieme H, Iwamoto MA, Park JE, Nguyen HV, Aiello LM, Ferrara N, King GL: Vascular endothelial growth factor in ocular fluid of patients with diabetic retinopathy and other retinal disorders. N Engl J Med 1994;331:1480-1487.

-4 Khaliq A, Foreman D, Ahmed A, Weich H, Gregor Z, McLeod D, Boulton M: Increased expression of placenta growth factor in proliferative diabetic retinopathy. Lab Invest 1998;78:109-115.

-5 Campochiaro PA: Ocular neovascularization. J Mol Med 2013;91:311-321.

6 Antonetti DA, Barber AJ, Hollinger LA, Wolpert EB, Gardner TW: Vascular endothelial growth factor induces rapid phosphorylation of tight junction proteins occludin and zonula occludens 1. J Biol Chem 1999;274:23463-23467.

-7 Deissler HL, Deissler H, Lang GE: Inhibition of protein kinase C is not sufficient to prevent or reverse effects of VEGF165 on claudin-1 and permeability in microvascular retinal endothelial cells. Invest Ophthalmol Vis Sci 2010;51:535-542.

8 Deissler H, Deissler H, Lang GE: Inhibition of VEGF is sufficient to completely restore barrier malfunction induced by growth factors in microvascular retinal endothelial cells. Br J Ophthalmol 2011;95:1151-1156.

-9 Deissler HL, Deissler H, Lang GK, Lang GE: VEGF but not PIGF disturbs the barrier of retinal endothelial cells. Exp Eye Res 2013;115:162-171.

10 Deissler HL, Lang GK, Lang GE: Binding of VEGF-A is sufficient to abrogate the disturbing effects of VEGF-B together with VEGF-A on retinal endothelial cells. Graefes Arch Clin Exp Ophthalmol 2015;253:885-894.

11 Suarez S, McCollum GW, Bretz CA, Yang R, Capozzi ME, Penn JS: Modulation of VEGF-induced retinal vascular permeability by peroxisome proliferator-activated receptor- $\beta / \delta$. Invest Ophthalmol Vis Sci 2014;55:8232-8240. 


\section{Cellular Physiology Cell Physiol Biochem 2017;42:1493-1513 \begin{tabular}{ll|l} 
and Biochemistry & $\begin{array}{l}\text { DOI: 10.1159/000479213 } \\
\text { Published onlne: July 18, } 2017\end{array}$ & $\begin{array}{l}\text { ( ) 2017 The Author(s). Published by S. Karger AG, Basel } \\
\text { www.karger.com/cpb }\end{array}$ \\
\hline
\end{tabular} \\ Deissler et al.: Redundant VEGF-A Signaling Pathways Regulating Permeability of Retinal Endothelial Cells}

12 Cai J, Wu L, Qi X, Shaw L, Li Calzi S, Caballero S, Jiang WG, Vinores SA, Antonetti D, Ahmed A, Grant MB, Boulton ME: Placenta growth factor-1 exerts time-dependent stabilization of adherens junctions following VEGF-induced vascular permeability. PLoS One 2011;6:e18076.

13 Dejana E, Tournier-Lasserve E, Weinstein BM: The control of vascular integrity by endothelial cell junctions: molecular basis and pathological implications. Dev Cell 2009;16:209-221.

14 Jeong JH, Nguyen HK, Lee JE, Suh W: Therapeutic effect of apatinib-loaded nanoparticles on diabetesinduced retinal vascular leakage. Int J Nanomedicine 2016;11:3101-3109.

-15 Chen XL, Nam J-O, Jean C, Lawson C, Walsh CT, Goka E, Lim S-T, Tomar A, Tancioni I, Uryu S, Guan J-L, Acevedo LM, Weis SM, Cheresh DA, Schlaepfer DD: VEGF-induced vascular permeability is mediated by FAK. Dev Cell 2012;22:146-157.

16 Ferrara N: Vascular endothelial growth factor: basic science and clinical progress. Endocr Rev 2004;25:581-611.

-17 Wu HM, Yuan Y, Zawieja DC, Tinsley J, Granger HJ: Role of phospholipase C, protein kinase C, and calcium in VEGF-induced venular hyperpermeability. Am J Physiol Heart Circ Physiol 1999;276:H535-H542.

18 Pocok TM and Bates DO: In vivo mechanisms of vascular endothelial growth factor-mediated increased hydraulic conductivity of Rana capillaries. J Physiol 2001;534:479-488.

19 Breslin JW, Pappas PJ, Cerveira JJ, Hobson RW II, Durán WN: VEGF increases endothelial permeability by separate pathways involving ERK-1/2 and nitric oxide. Am J Physiol Heart Circ Physiol 2003;284:H92-H100.

20 Lal BK, Varma S, Pappas PJ, Hobson RW, Durán WN: VEGF increases permeability of the endothelial cell monolayer by activation of PKB/akt, endothelial nitric-oxide synthase, and MAP kinase pathways. Microvasc Res 2001;62:252-262.

21 Marumo T, Noll T, Schini-Kerth VB, Harley EA, Duhault J, Piper HM, Busse R: Significance of nitric oxide and peroxynitrite in permeability changes of the retinal microvascular endothelial cell monolayer induced by vascular endothelial growth factor. J Vasc Res 1999;36:510-515.

-22 Becker PM, Verin AD, Booth MA, Liu F, Birukova A, Garcia GN: Differential regulation of diverse physiological responses to VEGF in pulmonary endothelial cells. Am J Physiol Lung Cell Mol Physiol 2001;281:L1500-L1511.

23 Sun H, Breslin JW, Zhu J, Yuan SY, Wu MH: Rho and ROCK signaling in VEGF-induced microvascular endothelial hyperpermeability. Microcirculation 2006;13:237-247.

-24 Wei J, Jiang H, Gao H, Wang G: Blocking mammalian target of rapamycin (mTOR) attenuates HIF- $1 \alpha$ pathways engaged-vascular endothelial growth factor (VEGF) in diabetic retinopathy. Cell Physiol Biochem 2016;40:1570-1577.

-25 Harhaj NS, Felinski EA, Wolpert EB, Sundstrom JM, Gardner TW, Antonetti DA: VEGF activation of protein kinase $\mathrm{C}$ stimulates occludin phosphorylation and contributes to endothelial permeability. Invest Ophthalmol Vis Sci 2006;47:5106-5115.

26 Sun M, Fu H, Cheng H, Cao Q, Zhao Y, Mou X, Zhang X, Liu X, Ke Y: A dynamic real-time method for monitoring epithelial barrier function in vitro. Anal Biochem 2012;425:96-103.

- 27 Ishimoto Y, Hirota-Takahata Y, Kurosawa E, Chiba J, Iwadate Y, Onozawa Y, Hasegawa T, Tamura A, Tanaka M, Kobayashi H: A novel natural product-derived compound, vestaine A1, exerts both pro-angiogenic and antipermeability activity via a different pathway from VEGF. Cell Physiol Biochem 2016;39:1905-1918.

-28 Lindsley CW, Zhao Z, Leister WH, Robinson RG, Barnett SF, Defeo-Jones D, Jones RE, Hartman GD, Huff JR, Huber HE, Duggan ME: Allosteric Akt (PKB) inhibitors: discovery and SAR of isozyme selective inhibitors. Bioorg Med Chem Lett 2005;15:761-764.

29 Toullec D, Pianetti P, Coste H, Bellevergue P, Grand-Perret T, Ajakane M, Baudet V, Boissin P, Boursier E, Loriolle F, Duhamel L, Charon D, Kirilovsky J: The bisindolylmaleimide GF 109203X is a potent and selective inhibitor of protein kinase C. J Biol Chem 1991;266:15771-15781.

-30 Kase H, Iwahashi K, Nakanishi S, Matsuda Y, Yamada K, Takahashi M, Murakata C, Sato A, Kaneko M: K-252 compounds, novel and potent inhibitors of protein kinase $\mathrm{C}$ and cyclic nucleotide-dependent protein kinases. Biochem Biophys Res Commun 1987;142:436-440.

-31 Rees DD, Palmer RM, Schulz R, Hodson HF, Moncada S: Characterization of three inhibitors of endothelial nitric oxide synthase in vitro and in vivo. Br J Pharmacol 1990;101:746-752.

-32 Hu L, Zaloudek C, Mills GB, Gray J, Jaffe RB: In vivo and in vitro ovarian carcinoma growth inhibition by a phosphatidylinositol 3-kinase inhibitor (LY294002). Clin Cancer Res 2000;6:880-886. 


\section{Cellular Physiology Cell Physiol Biochem 2017;42:1493-1513 \begin{tabular}{ll|l} 
and Biochemistry & $\begin{array}{l}\text { DOI: 10.1159/000479213 } \\
\text { Published onlne: July 18, } 2017\end{array}$ & $\begin{array}{l}\text { ( ) 2017 The Author(s). Published by S. Karger AG, Basel } \\
\text { www.karger.com/cpb }\end{array}$ \\
\hline
\end{tabular} \\ Deissler et al.: Redundant VEGF-A Signaling Pathways Regulating Permeability of Retinal Endothelial Cells}

-33 Roberts WG, Ung E, Whalen P, Cooper B, Hulford C, Autry C, Richter D, Emerson E, Lin J, Kath J, Coleman K, Yao L, Martinez-Alsina L, Lorenzen M, Berliner M, Luzzio M, Patel N, Schmitt E, LaGreca S, Jani J, Wessel M, Marr E, Griffor M, Vajdos F: Antitumor activity and pharmacology of a selective focal adhesion kinase inhibitor, PF-562,271. Cancer Res 2008;68:1935-1944.

-34 Dudley DT, Pang L, Decker SJ, Bridges AJ, Saltiel AR: A synthetic inhibitor of the mitogen-activated protein kinase cascade. Proc Natl Acad Sci USA 1995;92:7686-7689.

-35 Nam JS, Ino Y, Sakamoto M, Hirohashi S: Src family kinase inhibitor PP2 restores the E-cadherin/catenin cell adhesion system in human cancer cells and reduces cancer metastasis. Clin Cancer Res 2002;8:24302436.

-36 Knight ZA, Gonzalez B, Feldman ME, Zunder ER, Goldenberg DD, Williams O, Loewith R, Stokoe D, Balla A, Toth B, Balla T, Weiss WA, Williams RL, Shokat KM: A pharmacological map of the PI3-K family defines a role for p110alpha in insulin signaling. Cell 2006;125:733-747.

-37 Hennequin LF, Allen J, Breed J, Curwen J, Fennell M, Green TP, Lambert-van der Brempt C, Morgentin R, Norman RA, Olivier A, Otterbein L, Plé PA, Warin N, Costello G: N-(5-chloro-1,3-benzodioxol-4-yl)-7-[2(4-methylpiperazin-1-yl)ethoxy]-5- (tetrahydro-2H-pyran-4-yloxy)quinazolin-4-amine, a novel, highly selective, orally available, dual-specific c-Src/Abl kinase inhibitor. J Med Chem 2006;49:6465-88.

- 38 Bennet BL, Sasaki DT, Murray BW, O'Leary EC, Sakata ST, Xu W, Leisten JC, Motiwala A, Pierce S, Satoh Y, Bhagwat SS, Manning AM, Anderson DW: SP600125, an anthrapyrazolone inhibitor of Jun N-terminal kinase. Proc Natl Acad Sci USA 2001;98:13681-13686.

- 39 Nakamura K, Taguchi E, Miura T, Yamamoto A, Takahashi K, Bichat F, Guilbaud N, Hasegawa K, Kubo K, Fujiwara Y, Suzuki R, Kubo K, Shibuya M, Isae T: KRN951, a highly potent inhibitor of vascular endothelial growth factor receptor tyrosine kinases, has antitumor activities and affects functional vascular properties. Cancer Res 2006;66:9134-9142.

-40 Quiniou C, Sennlaub F, Beauchamp MH, Checchin D, Lahaie I, Brault S, Gobeil F Jr, Sirinyan M, Kooli A, Hardy P, Pshezhetsky A, Chemtob S: Dominant role for calpain in thromboxane-induced neuromicrovascular endothelial cytotoxicity. J Pharmacol Exp Ther 2006;316:618-627.

-41 Bonser RW, Thompson NT, Randall RW, Tateson JE, Spacey GD, Hodson HF, Garland LG: Demethoxyviridin and wortmannin block phospholipase $\mathrm{C}$ and $\mathrm{D}$ activation in the human neutrophil. Br J Pharmacol 1991;103:1237-1241.

-42 Uehata M, Ishizaki T, Satoh H, Ono T, Kawahara T, Morishita T, Tamakawa H, Yamagami K, Inui J, Maekawa M, Narumiya S: Calcium sensitization of smooth muscle mediated by a Rho-associated protein kinase in hypertension. Nature 1997;389:990-994.

43 Whittles CE, Pocock TM, Wedge SR, Kendrew J, Hennequin LF, Harper SJ, Bates DO: ZM323881, a novel inhibitor of vascular endothelial growth factor-receptor 2 tyrosine kinase activity. Microcirculation 2002;9:513-522.

-44 Ferrara N, Damico L, Shams N, Lowman H, Kim R: Development of ranibizumab, an anti-vascular endothelial growth factor antigen binding fragment, as therapy for neovascular age-related macular degeneration. Retina 2006;26:859-870.

-45 Deissler H, Deissler H, Lang GK, Lang GE: Generation and characterization of iBREC: novel hTERTimmortalized bovine retinal endothelial cells. Int J Mol Med 2005;15:65-70.

-46 Deissler HL, Lang GK, Lang GE: Capacity of aflibercept to counteract VEGF-stimulated abnormal behavior of retinal microvascular endothelial cells. Exp Eye Res 2014;122:20-31.

-47 Deissler HL, Lang GK, Lang GE: Neonatal Fc receptor FcRn is involved in intracellular transport of the Fc fusion protein aflibercept and its transition through retinal endothelial cells. Exp Eye Res 2017;154:39-46.

-48 Bates D, Mavrou A, Qiu Y, Carter JG, Hamdollah-Zadeh M, Barratt S, Gammons MV, Millar AB, Salmon AHJ, Oltean S, Harper SJ: Detection of VEGF-Axxxb isoforms in human tissues. PLoS One 2013;8:e68399. doi: 10.1371/journal.pone.0068399.

-49 Lang GE, Berta A, Eldem BM, Simader C, Sharp D, Holz FG, Sutter F, Gerstner O, Mitchell P; RESTORE Extension Study Group: Two-year safety and efficacy of ranibizumab $0.5 \mathrm{mg}$ in diabetic macular edema: interim analysis of the RESTORE extension study. Ophthalmology 2013;120:2004-2012.

-50 Li Q, Verma A, Han P-Y, Nakagawa T, Johnson RJ, Grant MB, Campell-Thompson M, Jarajapu YPR, Lei B, Hauswirth WW: Diabetic eNOS-knockout mice develop accelerated retinopathy. Invest Ophthalmol Vis Sci 2010;51:5240-5246. 


\section{Cellular Physiology Cell Physiol Biochem 2017;42:1493-1513

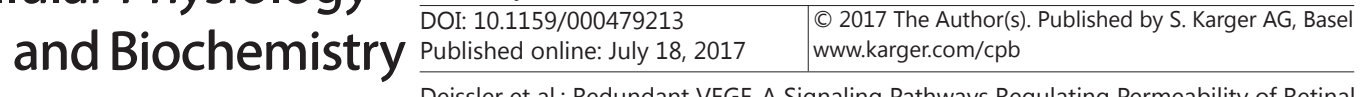 Endothelial Cells}

-51 Meyer M, Clauss M, Lepple-Wienhues A, Waltenberger J, Augustin HG, Ziche M, Lanz C, Buttner M, Rziha HJ, Dehio C: A novel endothelial growth factor encoded by Orf virus, VEGF-E, mediates angiogenesis via signaling through VEGFR-2 (KDR) but not VEGFR-1 (Flt-1) receptor kinases. EMBO J 1999;18:363-374.

52 Browning AC, Halligan EP, Stewart EA, Swan CD, Dove R, Samaranayake GF, Amoaku WM: Comparative gene expression profiling of human umbilical vein endothelial cells and ocular vascular endothelial cells. Br J Ophthalmol 2012;96:128-132.

-53 Scheppke, L, Aguilar E, Gariano RF, Jacobson R, Hood J, Doukas J, Cao J, Noronha G, Yee S, Weis S, Martin MB, Soll R, Cheresh DA, Friedlander M: Retinal vascular permeability suppression by topical application of a novel VEGFR2/Src kinase inhibitor in mice and rabbits. J Clin Invest 2008;118:2337-2346.

-54 Zhang Y, Furumura M, Morita E: Distinct signaling pathways confer different vascular responses to VEGF121 and VEGF165. Growth Factors 2008;26:125-131.

-55 Felinski EA, Cox AE, Phillips BE, Antonetti DA: Glucocorticoids induce transactivation of tight junction genes occludin and claudin-5 in retinal endothelial cells via a novel cis-element. Exp Eye Res 2008;86:867878.

-56 Aveleira CA, Lin C-M, Abcouwer SF Ambrosio AF, Antonetti DA: TNF- $\alpha$ signals through PKC /NF- $\kappa B$ to alter the tight junction complex and increase retinal endothelial cell permeability. Diabetes 2010;59:2782-2882.

-57 Deissler HL, Lang GK, Lang GE: Internalization of bevacizumab by retinal endothelial cells and its intracellular fate: evidence for an involvement of the neonatal Fc receptor. Exp Eye Res 2016;143:49-59.

58 Zhang Y, Ye M, Chen LJ, Li M, Tang Z, Wang C: Role of the ubiquitin-proteasome system and autophagy in regulation of insulin sensitivity in serum-starved 3T3-L1 adipocytes. Endocr J 2015;62:673-686.

-59 Junghans RP, Anderson CL: The protection receptor for IgG catabolism is the $\beta 2$-microglobulin-containing neonatal intestinal transport receptor. Proc Natl Acad Sci USA 1996;93:5512-5516.

60 Wilson SH, Ljubimov AV, Morla AO, Caballero S, Shaw LC, Spoerri PE, Tarnuzzer RW, Grant MB: Fibronectin fragments promote human retinal endothelial cell adhesion and proliferation and ERK activation through $\alpha 5 \beta 1$ integrin and PI 3-kinase. Invest Ophthalmol Vis Sci 2003;44:1704-1715.

61 Li G, D’Souza-Schorey C, Barbieri MA, Roberts RL, Klippel A, Williams LT, Stahl PD: Evidence for phosphatidylinositol 3-kinase as a regulator of endocytosis via activation of Rab5. Proc Natl Acad Sci USA 1995;92:10207-10211.

62 Weber ML, Liang MC, Flaherty KT, Heier JS: Subretinal fluid associated with MEK inhibitor use in the treatment of systemic cancer. JAMA Ophthalmol 2016;134:855-862.

63 PKC-DRS Study Group: The effect of ruboxistaurin on visual loss in patients with moderately severe to very severe nonproliferative diabetic retinopathy: initial results of the Protein Kinase C beta Inhibitor Diabetic Retinopathy Study (PKC-DRS) multicenter randomized clinical trial. Diabetes 2005;54:2188-2197. 